Article

\title{
Fast-Tracking Isolation, Identification and Characterization of New Microalgae for Nutraceutical and Feed Applications
}

\author{
Boer Bao, Skye R. Thomas-Hall and Peer M. Schenk *
}

Citation: Bao, B.; Thomas-Hall, S.R.; Schenk, P.M. Fast-Tracking Isolation, Identification and Characterization of New Microalgae for Nutraceutical and Feed Applications. Phycology 2022, 2, 86-107. https://doi.org/ $10.3390 /$ phycology2010006

Academic Editor: José

Lucas Pérez-Lloréns

Received: 15 December 2021

Accepted: 13 January 2022

Published: 16 January 2022

Publisher's Note: MDPI stays neutral with regard to jurisdictional claims in published maps and institutional affiliations.

Copyright: (C) 2022 by the authors. Licensee MDPI, Basel, Switzerland. This article is an open access article distributed under the terms and conditions of the Creative Commons Attribution (CC BY) license (https:// creativecommons.org/licenses/by/ $4.0 /)$.
Algae Biotechnology Laboratory, School of Agriculture and Food Sciences, The University of Queensland, Brisbane QLD 4072, Australia; boer.bao@uqconnect.edu.au (B.B.); s.thomashall@uq.edu.au (S.R.T.-H.)

* Correspondence: p.schenk@uq.edu.au

\begin{abstract}
Microalgae contain high-value biochemical compounds including fatty acids (FA), protein and carotenoids, and are promising bioresources to enhance nutrition of food and animal feed. Important requirements for commercial strains are rapid growth and high productivities of desirable compounds. As these traits are believed to be found in aquatic environments with fluctuating conditions, we collected microalgae from marine and freshwater environments that are subjected to eutrophication and/or tidal fluctuations. Using this directed approach, 40 monoalgal cultures were isolated and 25 identified through $18 \mathrm{~S}$ rDNA sequencing and morphological characterization. Based on their high growth rates $\left(0.28-0.60\right.$ day $\left.^{-1}\right)$ and biomass productivities $\left(0.25-0.44 \mathrm{~g} \mathrm{~L}^{-1}\right.$ day $\left.^{-1}\right)$ in commercial fertilizer under standardized conditions, six new strains were selected. Scenedesmus sp. GW63 produced quality FA-rich biomass with high omega-3 polyunsaturated FA $(28.5 \%$ of total FA (TFA)) contents, especially $\alpha$-linolenic acid (ALA; $20.0 \%$ of TFA) with a very low $n-6 / n-3$ ratio (0.4), and high FA productivity (32.6 $\left.\mathrm{mg} \mathrm{L}^{-1} \mathrm{day}^{-1}\right)$. A high protein productivity $\left(34.5 \mathrm{mg} \mathrm{L}^{-1} \mathrm{day}^{-1}\right.$ ) made Desmodesmus sp. UQL1_26 (33.4\% of dry weight (DW)) attractive as potential protein-rich feed and nutrition supplement. Monoraphidium convolutum GW5 displayed valuable carotenoid production $(0.8 \% \mathrm{DW})$ with high carotenoid accumulation capability $\left(0.8 \mathrm{mg} \mathrm{L}^{-1} \mathrm{day}^{-1}\right)$. This research provides a pathway for fast-tracking the selection of high-performing local microalgae from different environments for nutraceuticals, functional foods and animal feed applications.
\end{abstract}

Keywords: $18 \mathrm{~S}$ rDNA sequencing; algal protein; biomass productivity; carotenoids; fatty acid profiling; microalgae selection

\section{Introduction}

Microalgae are promising bioresources that contain a wide array of valuable bioproducts to enhance the nutritional value of food and animal feed. Some of these unicellular and multicellular photosynthetic microorganisms are opportunistic and can grow rapidly under favorable conditions but also survive under extreme environmental conditions. Microalgae are highly abundant and have a rich biodiversity, with more than 72,500 species [1]. The numerous advantages of cultivating microalgae over terrestrial plants for food and feed applications are widely recognized: higher growth rates [2] and biomass productivities per land area [3]; cultivation on non-arable land [2-5]; high efficiencies in reducing greenhouse gas emission and removing $\mathrm{CO}_{2}$ from industrial flue gases by algae bio-fixation [6,7] .

Based on their potentially high biomass productivity and rich biochemical composition, there has been much interest to use microalgae for a diverse range of commercial applications. This includes the use of microalgae as renewable energy sources such as biodiesel or biocrude oils [4,5,8,9], wastewater bioremediation [10], photosynthetic gas exchangers for space travel [11], cosmetics [12], nutraceuticals [13,14], functional foods [13], and feed additives $[15,16]$. While there is potential for microalgae-based biofuels, the high cost of microalgae production makes such low-value commodities unfeasible under current market conditions $[4,13,17]$. Most promising at the current state-of-the-art is therefore to 
develop high-value, commercial products such as nutraceuticals, functional foods and animal feed additives $[13,16,17]$. Of particular interest for these high-value products are biochemical compounds, such as fatty acids, protein and carotenoids, which have clear health-promoting properties $[13,16,17]$.

Microalgae are rich sources of lipids with total lipid contents commonly ranging between 5 and $20 \%$ of the dry weight (DW) and in excess of $20 \%$ up to $80 \%$ DW in some species under stressed or unfavorable conditions [18]. Although the total lipid content is commonly reported for microalgae, quantification of the content of total fatty acids (TFA) and fatty acid composition is the essential criterion for identifying suitable microalgal strains for nutraceuticals, food and feed applications. Food or feed with a high proportion of omega-3 PUFA is considered favorable for health and nutrition. In particular, omega-3 PUFA such as C18:3(n-3) $\alpha$-linolenic acid (ALA), C20:5(n-3) eicosapentaenoic acid (EPA), and C22:6(n-3) docosahexaenoic acid (DHA) are nutritionally valuable products that promote cardiovascular and circulatory health in humans as well as growth and health in aquaculture species [2]. Traditionally, omega-3 PUFA are derived from wild fish oil. However, much concern has been raised in regard to unsustainable fishing [19], the presence of chemical contaminants and the vegetarian consumption dilemma [20]. Thus, the demand for microalgae-based omega-3 PUFA is rapidly increasing.

Protein quality and quantity are also key factors in measuring the nutritional value of microalgae for foods, health products and animal feeds $[16,21]$. While algae can synthesize all amino acids, humans and animals must take up essential amino acids from food [16,21]. Almost all microalgae have high-quality amino acids that are superior to conventional food proteins [21]. Furthermore, the crude protein content generally makes up a large fraction of their actively growing biomass $[15,22]$. This is one of the main reasons to consider microalgae as an excellent alternative source of protein [16,21]. A prominent example is Spirulina sp. which can yield up to $46-71 \%$ DW of high-quality protein and is widely used for functional foods and nutraceuticals [15]. Protein-rich microalgae can be used in animal nutrition and aquaculture feed [16]. Specifically, several trials of utilizing microalgae as an alternative protein feed supplement have been performed on poultry and ruminants, and significantly higher growth rates and lower non-specific mortality rates were observed [21]. The overall protein production for food or food substitutes has not been fully exploited, despite its high nutritious content [15].

Algae can produce a greater variety of carotenoids than higher plants [21,23,24]. Microalgae-derived carotenoids are commercially exploited as natural food colorants, antioxidants, animal feed additives, and cosmetics [16]. Specifically, $\beta$-carotene can be converted into vitamin A by the human metabolism [17] and the consumption of a rich $\beta$-carotene diet can reduce the chance of developing several types of cancer and degenerative diseases [21]. Dunaliella salina is a well-commercialized species that has a high content (up to $14 \%$ DW under certain stressed conditions) of $\beta$-carotene $[13,16]$. Astaxanthin is a powerful antioxidant that is also used by the aquaculture industry to refine coloration characteristics of fish and crustaceans [16]. The commercial species Haematococcus pluvialis contains the highest amount of astaxanthin $(1.5-3.0 \%$ DW) in any natural source $[13,14,25]$. Although the current market is dominated by chemically-synthesized carotenoids, the natural forms of these, produced by microalgae, do contribute to a large share $[13,16,17]$. In addition, the natural carotenoid industry is substantially growing due to the decreased use of synthetic food additives as some of these are suspected to possess carcinogenic, liver and renal toxicity properties [21].

Irrespective of different growth conditions, such as growth phase, culture medium, light irradiance, and temperature, the biochemical composition of microalgae, including the total lipid content $[14,18,26]$, fatty acid composition $[2,14,27,28]$, total protein content $(10 \%$ to $71 \%$ DW) $[15,29]$, and total carotenoid content $(0.1 \%$ to $14 \%$ DW) $[16,30]$, varies significantly between species. The use of local dominant microalgae with high growth rates and high productivities of desirable compounds is considered superior to using non-native (exotic) strains, as these may not be well adapted to local environments and may pose 
an ecological risk as invasive species [5]. However, this is contrary to most commercial microalgae operations who typically only use less than a dozen strains. Despite the fact that algae have numerous potentials and benefits to be utilized in human and animal nutrition and their high biodiversity, only few species are currently commercialized in the market.

Much effort needs to be made to investigate 'wild' local microalgal strains from unique and diverse aquatic environments with capacities of more efficient biocompound production [18]. Significant opportunities exist to identify, assess and select promising local strains, based on rapid growth in agricultural fertilizers, high biomass productivity, easy harvesting capability, high protein, carotenoid and oil content and quality, all of which are key properties for successful commercialization. As the algae industry is expanding, there is a need to fast-track effective isolation and characterization of high-performing local strains. An important foundation step is to rapidly identify, assess growth/harvesting properties, and profile and quantify the biochemical composition of local microalgae to target high-value natural compounds for nutraceuticals, food and animal feeds. The current study provides a pathway for the rapid selection of local high-performing strains by sampling from fluctuating and extreme environments, where opportunistic microalgae with high compound inducibility are likely to preferentially reside. Following isolation and identification, standardized protocols for cultivation, harvesting and compound profiling were used.

\section{Materials and Methods}

\subsection{Microalgae Sample Collection and Isolation}

In an effort to streamline the sampling of robust and fast-growing microalgae, water samples of microalgae were collected from a great variety of local fluctuating aquatic environments, such as freshwater lakes and ponds (subject to sporadic eutrophication), as well as environments with tidal fluctuating conditions such as a brackish river, an estuary and a coastal rocky beach of subtropical regions in Queensland, Australia (for exact location see Results section). All samples were filtered through a 50-micron-filter mesh and initially cultivated with F/2 medium (Algaboost F/2 (2000×) silicate free, AusAqua, Wallaroo, Australia) [31] for 2 weeks. Pure cultures were then isolated by micromanipulation and agar plate streaking, and subsequently kept as stock cultures following the rapid isolation protocol by Duong et al. [32,33]. In addition, one promising strain from the Northern Territory, Scenedesmus dimorphus NT8C, from the Queensland Microalgae Collection at the University of Queensland, Brisbane, Australia [34] was included in this study as a benchmark strain. All microalgal stock cultures were enriched with agricultural-grade fertilizer nutrients (Table 1) and were maintained in $50 \mathrm{~mL}$ Erlenmeyer flasks with constant orbital shaking $(100 \mathrm{rpm})$ at $25 \pm 2{ }^{\circ} \mathrm{C}$, under $24 \mathrm{~h}$ white fluorescent light $\left(120 \mu \mathrm{mol}\right.$ photons $\left.\mathrm{m}^{-2} \mathrm{~s}^{-1}\right)$. As axenic cultures often produce low biomass productivity [25], xenic, monoalgal cultures (with associated bacteria still present) were maintained and sub-cultured every three weeks. All microalgal cultures were routinely examined under a compound microscope (Olympus CX21LED, Notting Hill, Australia) for other microalgal contamination or visible bacterial presence during exponential algal growth.

Table 1. Composition of the fertilizer-grade nutrients used in this study.

\begin{tabular}{cccc}
\hline Chemical & Producer & $\begin{array}{c}\text { Amount Added } \\
\left(\mathbf{m g ~ L}^{-1}\right)\end{array}$ & $\begin{array}{c}\text { Final Concentration } \\
\text { in the Media }(\boldsymbol{\mu M})\end{array}$ \\
\hline $\mathrm{NH}_{4} \mathrm{H}_{2} \mathrm{PO}_{4}$ & Yates, Orica Australia Pty Ltd. & 17.25 & 150 \\
$\mathrm{KNO}_{3}$ & Biolab (Aust) Ltd. & 164 & 1624 \\
$\mathrm{MgSO}_{4} \cdot 7 \mathrm{H}_{2} \mathrm{O}$ & Chem Supply & 82 & 333 \\
$\mathrm{Sea} \mathrm{salt}$ & Aquasonic & 25 & 431 \\
RapiSol Mi6 EDTA Chelated Micro Nutrient & Agspec Australia Pty Ltd. & 4 & N/A \\
RapiSol Iron EDTA Chelated Micro Nutrient & Agspec Australia Pty Ltd. & 4 & N/A \\
\hline
\end{tabular}




\subsection{Standardized Cultivation and Growth Experiments}

Based on pre-screening criteria of fast growth, ease of harvesting (settling properties), and easy cultivation in fertilizer media, seven microalgal strains were pre-selected for the growth experiment (see Results section). In order to promote health of cultures and standardize cell densities, recent stock cultures were used as inoculums and initially cultured for 4 days till they reached late logarithmic (late log) phase in fertilizer medium (Table 1). Nitrate concentrations were measured with the Nitrate $\left(\mathrm{NO}^{3-}\right.$ ) Test Kit (API Aquarium Pharmaceuticals) on day 4 to ensure cultures contained adequate nutrients, prior to the growth experiments. A total of $50 \mathrm{~mL}$ of inoculated algal cultures was used to start the standardized growth experiment with $450 \mathrm{~mL}$ fertilizer medium. All cultures were maintained in $500 \mathrm{~mL}$ Erlenmeyer flasks with aeration (without external $\mathrm{CO}_{2}$ supply) at a temperature and light controlled laboratory $\left(25 \pm 2{ }^{\circ} \mathrm{C}, 16 \mathrm{~h}: 8 \mathrm{~h}\right.$ light:dark cycle, $150 \mu \mathrm{mol}$ photons $\mathrm{m}^{-2} \mathrm{~s}^{-1}$ light from white LED lights). Three replicates of each strain were cultured, harvested and analyzed separately. Growth experiments were carried out for 3-5 days, then $250 \mathrm{~mL}$ of algal cultures in late log phase were harvested through centrifugation at $1700 \times g$ for 5 min. Cell culture densities (haemocytometer, Blaubrand, Merck, Bayswater, Australia) and nutrient concentrations were measured daily. As lipid production increased in some microalgal species under nutrient deprivation $[2,3,14,35]$, the remaining nutrient deprived cultures were further cultivated for 2 days to induce lipid production. A total of $100 \mathrm{~mL}$ of remaining biomass was harvested and centrifuged at $1700 \times g$ for $5 \mathrm{~min}$. After nutrient deprivation, $2 \mathrm{~mL}$ of microalgal cultures were stained with $0.5 \mathrm{mg} \mathrm{mL}^{-1}$ Nile red (Sigma-Aldrich, dissolved in dimethyl sulfoxide) for $15 \mathrm{~min}$ and photographed under a compound microscope (Zeiss AX10, AxioCam MRc camera, Oberkochen, Germany) with epifluorescent light (excitation: 510-550 nm, emission: $590 \mathrm{~nm}$ ). All harvested biomass was frozen at $-80^{\circ} \mathrm{C}$ and lyophilized for 3 days. Biomass used for protein analysis was stored at $-20^{\circ} \mathrm{C}$ and the remaining biomass was stored at $-80^{\circ} \mathrm{C}$ till further analyses. The average growth rate [36] was calculated using the equation:

$$
\mu=\ln \left(N_{y} / N_{x}\right) /\left(t_{y}-t_{x}\right)
$$

where $\mathrm{Nx}$ was the number of cells at the start (tx) of the growth period (5-7 days) and $\mathrm{Ny}$ was the number of cells at the end (ty) of the growth period. The average doubling time [2] was calculated using the equation:

$$
\mathrm{T}=\left(\mathrm{t}_{\mathrm{y}}-\mathrm{t}_{\mathrm{x}}\right) / \log _{2}\left(\mathrm{~N}_{\mathrm{x}} / \mathrm{N}_{\mathrm{y}}\right)
$$

Biomass productivities $\left(\mathrm{g} \mathrm{L}^{-1}\right.$ day $^{-1}$ ) were calculated as total DW over the duration of the growth experiment (late log phase (3-5 days, LL), average of the total growth experiment period (5-7 days, AVE), and the nutrient depleted period ( 2 days, ND)).

\subsection{DNA Isolation, Sequencing and Identification}

Genomic DNA was extracted from $15 \mathrm{~mL}$ fresh algal stock cultures of each strain using a DNeasy Plant Mini Kit (Qiagen) following the manufacturer's instructions. DNA amplification for the partial sequence of $18 \mathrm{~S}$ rRNA gene was performed by polymerase chain reaction (PCR) with the following primers: Forward: 5'-GCGGTAATTCCAGCTCCAATAGC- $3^{\prime}$ and Reverse: $5^{\prime}$-GACCATACTCCCCCCGGAACC-3'. PCR was performed in a $25 \mu \mathrm{L}$ mixture containing 1.25 U/ $\mu \mathrm{L}$ TAQ DNA Polymerase (Scientifix, Clayton, Australia), $1 \times$ Reaction Buffer with $2 \mathrm{mM} \mathrm{MgCl}_{2}$ (Scientifix, Clayton, Australia), $200 \mu \mathrm{M}$ dNTP mix (Scientifix, Clayton, Australia), $0.25 \mu \mathrm{M}$ of each primer, $18.75 \mu \mathrm{L}$ of UltraPure Distilled Water (Thermo Fisher Scientific, Waltham, MA, USA) and $1 \mu \mathrm{L}$ of genomic DNA (10-25'ng), and amplified on a Bio-Rad DNA Engine PCR machine with the following cycling profile: initialization at $94{ }^{\circ} \mathrm{C}$ for $5 \mathrm{~min}$, denaturation at $94{ }^{\circ} \mathrm{C}$ for $30 \mathrm{~s}$, annealing at $55^{\circ} \mathrm{C}$ for $30 \mathrm{~s}$, extension at $72{ }^{\circ} \mathrm{C}$ for $1 \mathrm{~min}$, final extension at $72{ }^{\circ} \mathrm{C}$ for $10 \mathrm{~min}$. PCR products were purified using a Wizard SV Gel PCR Clean-Up System (Promega, Madison, WI, USA). A volume of $5 \mu \mathrm{L}$ of purified DNA ( $25 \mathrm{ng}$ ) was mixed with $0.83 \mu \mathrm{M}$ of each primer separately, topped up 
to $12 \mu \mathrm{L}$ in a final volume with UltraPure Distilled Water and sequenced in both directions by the Australian Genome Research Facility in Brisbane, Australia.

Sequences were manually checked, edited and submitted to GenBank (Table 1). DNA sequences were searched and compared using nucleotide BLAST in GenBank (http:/ / blast.ncbi.nlm.nih.gov / Blast.cgi, accessed on 27 October 2015). Based on BLAST results, closely related sequences in preference to published peer reviewed journal articles were downloaded and included for constructing the phylogenetic tree. Species names were assigned to sequences with $100 \%$ identity match, whereas genus names were adopted with $99 \%$ identity match. When sequence identity was less than a $99 \%$ match or was matched with multiple genera, morphological taxonomy and phylogenetic trees were used to identify the genus of strains. A total of 38 sequences (13 from GenBank and 25 from this study) were aligned and trimmed into standard size in MEGA 6.06. The maximum parsimony phylogenetic tree was constructed in MEGA 6.06 using the Subtree-PruningRegrafting (SPR) algorithm and was drawn to scale, with branch lengths calculated using the average pathway method [37,38]. The alignment consisted of 397 positions. Gaps and missing data from all positions were eliminated. The bootstrap test (1000 replicates) was used to estimate the reliability of the phylogenetic tree [39].

\subsection{Fatty Acid Methyl Ester (FAME) Analyses}

Lyophilized algal biomass ( $5 \mathrm{mg}$ ) was hydrolyzed and methyl-esterified in $300 \mu \mathrm{L}$ of a $2 \%(v / v) \mathrm{H}_{2} \mathrm{SO}_{4}$ methanol solution for $2 \mathrm{~h}$ at $80^{\circ} \mathrm{C}$ with $50 \mu \mathrm{g} \mathrm{C21:0} \mathrm{(heneicosanoic} \mathrm{acid,}$ Sigma-Aldrich, St. Louis, MO, USA) as an internal recovery standard. A total of $300 \mu \mathrm{L}$ of hexane and $300 \mu \mathrm{L}$ of $0.9 \%(w / v) ~ \mathrm{NaCl}$ were added to the mixture. The mixture was vortexed for $20 \mathrm{~s}$ and centrifuged at $16,000 \times g$ for $3 \mathrm{~min}$ to facilitate phase separation. A total of $150 \mu \mathrm{L}$ of the hexane layer was injected into an Agilent 6890 gas chromatograph connected to a 5975 MSD mass spectrometer. The running conditions of Agilent's RTL DBWax method (Application note: 5988-5871EN) was set up as described previously [2]. Fatty acids were identified by comparing retention times with pre-run external standards (37 FAME Mix, Supelco, identified through the NIST library). A linear calibration curve based on the internal standard C22:4(n-6) (adrenic acid) and the internal recovery standard C21:0 were used for fatty acid quantification. TFA content was determined as the sum of all fatty acids. TFA productivity $\left(\mathrm{mg} \mathrm{L}^{-1} \mathrm{day}^{-1}\right)$ was calculated as TFA multiplied by the average biomass productivity over the entire growth period.

\subsection{Total Protein Analyses}

The protein content was measured by the Lowry method ([22,40] 1951) with slight modifications. A total of $10 \mathrm{mg}$ of crushed, lyophilized algal biomass was suspended in $10 \mathrm{~mL}$ of lysis buffer $\left(5 \mathrm{~mL} \mathrm{~L}^{-1}\right.$ of Triton X-100, Chem Supply; $0.37 \mathrm{~g} \mathrm{~L}^{-1}$ ethylenediaminetetraacetic acid disodium salt, Chem Supply; $0.03 \mathrm{~g} \mathrm{~L}^{-1}$ of phenyl methyl sulfonyl fluoride, Sigma-Aldrich, St. Louis, MO, USA) for $30 \mathrm{~min}$. Then, $0.1 \mathrm{~mL}$ of SDS solution $\left(0.05 \mathrm{~g} \mathrm{~L}^{-1}\right.$ of sodium dodecyl sulfate salt, Sigma-Aldrich, St. Louis, MO, USA) was added into $0.1 \mathrm{~mL}$ of the lysis buffer mixture and mixed by vortexing. The reaction mixture was used for extracting proteins with a CB-X Protein Assay Kit (G-Biosciences, St. Louis, MO, USA) following the manufacturer's instructions. A microplate photometer (Glomax Multi Detection System, Promega, Madison, WI, USA) was used to obtain the absorbance at wavelength $600 \mathrm{~nm}$. The absorbance was then converted into protein concentration using a linear calibration curve (correlation coefficient was 0.995) established by the absorbance range of $0.2^{-1}$ corresponding to the bovine serum albumin (BSA) standard concentration of $0-1 \mathrm{mg} \mathrm{mL}^{-1}$. The protein content of the biomass was calculated using the equation:

$$
\text { Protein }(\%, \mathrm{DW})=\mathrm{CVD} / \mathrm{m} \times 100
$$

where $\mathrm{C}$ was the protein concentration $\left(\mathrm{mg} \mathrm{L}^{-1}\right)$ obtained from the calibration curve, $\mathrm{V}$ was the volume (L) of the lysis buffer, $\mathrm{D}$ was the dilution factor, and $\mathrm{m}$ was the amount of 
biomass $(\mathrm{mg})$ [22]. Protein productivity $\left(\mathrm{mg} \mathrm{L}^{-1} \mathrm{day}^{-1}\right)$ was calculated as the total protein content multiplied by the biomass productivity during the late log phase.

\subsection{Total Carotenoid Analyses}

The total carotenoid extraction was carried out as previously described [36,41,42]. Briefly, $10 \mathrm{~mL}$ of $90 \%$ acetone (Merck KGaA, HPLC grade, Bayswater, Australia) was added to $10 \mathrm{mg}$ of crushed lyophilized algal sample and mixed by vortexing. The mixture was then kept in the dark for $24 \mathrm{~h}$ at $4{ }^{\circ} \mathrm{C}$. A spectrophotometer (Hitachi U-2800, Tokyo, Japan) was used to obtain the absorbance of the solvent at wavelengths 470, 646.6 and $663.6 \mathrm{~nm}$. The carotenoid content of the biomass was calculated using the following equations:

$$
\begin{gathered}
C_{a}=12.25 A_{663.2}-2.79 A_{646.8} \\
C_{b}=21.50 A_{646.8}-5.10 A_{663.2} \\
C_{x+c}=\left(1000 A_{470}-1.82 C_{a}-85.02 C_{b}\right) / 198 \\
\text { Carotenoids }\left(\mathrm{mg} \mathrm{g}^{-1} \mathrm{DW}\right)=\left(C_{x+c} \times \mathrm{V}\right) /(m \times 1000)
\end{gathered}
$$

where $\mathrm{V}$ was the volume $(\mathrm{mL})$ of the acetone and $\mathrm{m}$ was the amount of biomass $(\mathrm{g})$. Carotenoid productivity $\left(\mathrm{mg} \mathrm{L}^{-1}\right.$ day $\left.^{-1}\right)$ was calculated as the total carotenoid content multiplied by the biomass productivity during the late logarithmic phase.

\subsection{Statistical Analyses}

All results were obtained from three separately-grown replicate cultures (six replicates for reference strain S. dimorphus NT8C) and are shown as the mean values $\pm \mathrm{SE}$. Growth rate, doubling time and biomass productivity were analyzed by ANOVA followed by Tukey's test.

\section{Results}

\subsection{Sample Collection, Isolation and Identification}

A total of 40 microalgal strains were successively isolated and cultured from marine, brackish and freshwater environments that are subjected to frequent fluctuating conditions (eutrophication and/or tidal influences). Based on initial observations under a compound microscope, freshwater strains were dominated by Chlorophyceae, whereas marine strains were dominated by Bacillariophyceae. More than half of the marine algae were unhealthy (displaying lysed cells or fractured cell walls) and ultimately died upon culturing in agricultural fertilizer media, leaving 25 cultures. BLAST results of the 18S rRNA gene sequences were able to assign identity to 20 out of 25 isolated new strains, and those with less than $99 \%$ sequence identity matches were confirmed by morphological taxonomy and the maximum parsimony phylogenetic tree (Table 2, Figure 1).

UQL1_19 and UQL1_26 were identified as Desmodesmus sp. as they formed a wellsupported clade ( $99 \%$ bootstrap support) with Desmodesmus armatus (Genbank accession: KP281291 and KP281290), Desmodesmus communis (Genbank accession: KF864475), Desmodesmus armatus var. subalternans (Genbank accession: KF673362), and Desmodesmus opoliensis (Genbank accession: AB917107). The morphological description matched with this finding, where the formation of spines was the distinct difference between Desmodesmus and Scenedesmus [43]. Non-spiny strains were identified as Scenedesmus, while spiny strains were assigned into the genus Desmodesmus. The sequence of Scenedesmus sp. GW63 was 99\% identical to Scenedesmus parvus (Genbank accession: FR865718). UQL1_13 formed a distinct clade (99\% bootstrap support) with Ankistrodesmus gracilis (Genbank accession: Y16937) and Ankistrodesmus sp. (Genbank accession: KM676973), and therefore was assigned to Ankistrodesmus species. GW5 sequence was identical to the Genbank sample Monoraphidium convolutum (AY846377). However, this strain clustered with Ankistrodesmus sp. UQL1_13 rather than other Monoraphidium species. UQL1_20 had a sequence identity of $100 \%$ with Monoraphidium sp. (Genbank accession: AY846386 and AY846387) and Monoraphidium 
pusillum (Genbank accession: AY846383) and was ultimately identified as a Monoraphidium species. Clear monophyletic clades of Scenedesmaceae, Selenastraceae, Chlorophyceae, and Bacillariophyceae were formed in the 18S rRNA phylogeny in this study (Figure 1). Among the 25 identified new monoalgal strains (Table 2), six displayed initial fast growth, easy cultivation with agricultural fertilizer-grade nutrients and settling as an indicator of good harvesting potential (Figure 2). These were subjected to standardized growth and lipid induction experiments in triplicate cultures to allow a direct comparison.

Table 2. Origins and identities of isolated microalgal strains used in this study.

\begin{tabular}{|c|c|c|c|}
\hline Strain & Location & Fluctuating Environment & Genbank Accession \\
\hline Monoraphidium convolutum GW5 & $\begin{array}{l}\text { Woods Grains Pond, Goondiwindi } \\
28^{\circ} 32^{\prime} 03^{\prime \prime} \mathrm{S} 150^{\circ} 19^{\prime} 39^{\prime \prime} \mathrm{E}\end{array}$ & Eutrophic freshwater & KT893828 \\
\hline Scenedesmus sp. GW63 & $\begin{array}{l}\text { Woods Grains Pond, Goondiwindi } \\
28^{\circ} 31^{\prime} 37^{\prime \prime} \mathrm{S} 150^{\circ} 17^{\prime} 29^{\prime \prime} \mathrm{E}\end{array}$ & Eutrophic freshwater & KT893831 \\
\hline Ankistrodesmus sp. UQL1_13 & UQ Lake, St Lucia $27^{\circ} 29^{\prime} 55^{\prime \prime} \mathrm{S} 153^{\circ} 0^{\prime} 58^{\prime \prime} \mathrm{E}$ & Eutrophic freshwater & KT893832 \\
\hline Desmodesmus sp. UQL1_19 & UQ Lake, St Lucia $27^{\circ} 29^{\prime} 55^{\prime \prime} \mathrm{S} 153^{\circ} 0^{\prime} 58^{\prime \prime} \mathrm{E}$ & Eutrophic freshwater & KT893836 \\
\hline Monoraphidium sp. UQL1_20 & UQ Lake, St Lucia $27^{\circ} 29^{\prime} 55^{\prime \prime} \mathrm{S} 153^{\circ} 0^{\prime} 58^{\prime \prime} \mathrm{E}$ & Eutrophic freshwater & KT893837 \\
\hline Desmodesmus sp. UQL1_26 & UQ Lake, St Lucia $27^{\circ} 29^{\prime} 55^{\prime \prime} \mathrm{S} 153^{\circ} 0^{\prime} 58^{\prime \prime} \mathrm{E}$ & Eutrophic Ffeshwater & KT893841 \\
\hline Scenedesmus dimorphus NT8C & $\begin{array}{c}\text { Douglas Daly Research Farm, Winellie } \\
13^{\circ} 49^{\prime} 59^{\prime \prime} \mathrm{S} 131^{\circ} 11^{\prime} 12^{\prime \prime} \mathrm{E}\end{array}$ & High temperature freshwater & KF286273 \\
\hline Ochromonas sp. PH1_1 & $\begin{array}{l}\text { Algae Energy Farm open pond, Pinjarra Hills } \\
\qquad 27^{\circ} 32^{\prime} 21^{\prime \prime} \mathrm{S} 152^{\circ} 55^{\prime} 24^{\prime \prime} \mathrm{E}\end{array}$ & Eutrophic freshwater & KT804909 \\
\hline Spumella sp. GW31 & $\begin{array}{l}\text { Golf Course Pond, Goondiwindi } \\
28^{\circ} 31^{\prime} 45^{\prime \prime} \mathrm{S} 150^{\circ} 18^{\prime} 27^{\prime \prime} \mathrm{E}\end{array}$ & Eutrophic freshwater & KT893827 \\
\hline $\begin{array}{c}\text { Pseudodidymocystis planctonica } \\
\text { GW61 }\end{array}$ & $\begin{array}{l}\text { Woods Grains Pond, Goondiwindi } \\
28^{\circ} 31^{\prime} 37^{\prime \prime} \mathrm{S} 150^{\circ} 17^{\prime} 29^{\prime \prime} \mathrm{E}\end{array}$ & Eutrophic freshwater & KT893829 \\
\hline Scenedesmus sp. GW62 & $\begin{array}{l}\text { Woods Grains Pond, Goondiwindi } \\
28^{\circ} 31^{\prime} 37^{\prime \prime} \mathrm{S} 150^{\circ} 17^{\prime} 29^{\prime \prime} \mathrm{E}\end{array}$ & Eutrophic freshwater & KT893830 \\
\hline Pseudomuriella sp. UQL1_15 & UQ Lake, St Lucia $27^{\circ} 29^{\prime} 55^{\prime \prime} \mathrm{S} 153^{\circ} 0^{\prime} 58^{\prime \prime} \mathrm{E}$ & Eutrophic freshwater & KT893833 \\
\hline Kirchneriella sp. UQL1_16 & UQ Lake, St Lucia $27^{\circ} 29^{\prime} 55^{\prime \prime} \mathrm{S} 153^{\circ} 0^{\prime} 58^{\prime \prime} \mathrm{E}$ & Eutrophic freshwater & KT893834 \\
\hline Kirchneriella sp. UQL1_18 & UQ Lake, St Lucia $27^{\circ} 29^{\prime} 55^{\prime \prime} \mathrm{S} 153^{\circ} 0^{\prime} 58^{\prime \prime} \mathrm{E}$ & Eutrophic freshwater & KT893835 \\
\hline Desmodesmus sp. UQL1_22 & UQ Lake, St Lucia $27^{\circ} 29^{\prime} 55^{\prime \prime} \mathrm{S} 153^{\circ} 0^{\prime} 58^{\prime \prime} \mathrm{E}$ & Eutrophic freshwater & KT893838 \\
\hline Protodesmus sp. UQL1_23 & UQ Lake, St Lucia $27^{\circ} 29^{\prime} 55^{\prime \prime} \mathrm{S} 153^{\circ} 0^{\prime} 58^{\prime \prime} \mathrm{E}$ & Eutrophic freshwater & KT893839 \\
\hline Desmodesmus sp. UQL1_24 & UQ Lake, St Lucia $27^{\circ} 29^{\prime} 55^{\prime \prime} \mathrm{S} 153^{\circ} 0^{\prime} 58^{\prime \prime} \mathrm{E}$ & Eutrophic freshwater & KT893840 \\
\hline Nitzschia palea UQL1_31 & UQ Lake, St Lucia $27^{\circ} 29^{\prime} 55^{\prime \prime}$ S $153^{\circ} 0^{\prime} 58^{\prime \prime} \mathrm{E}$ & Eutrophic freshwater & KT893842 \\
\hline Chaetoceros calcitrans BR1_3 & $\begin{array}{l}\text { Brisbane River, Brisbane } \\
27^{\circ} 29^{\prime} 30^{\prime \prime} \mathrm{S} 153^{\circ} 0^{\prime} 47^{\prime \prime} \mathrm{E}\end{array}$ & Eutrophic tidal brackish & KT893843 \\
\hline Achnanthes sp. BR1_5 & $\begin{array}{l}\text { Brisbane River, Brisbane } \\
27^{\circ} 29^{\prime} 30^{\prime \prime} \mathrm{S} 153^{\circ} 0^{\prime} 47^{\prime \prime} \mathrm{E}\end{array}$ & Eutrophic tidal brackish & KT893844 \\
\hline Thalassiosira sp. NB1_1 & $\begin{array}{l}\text { Nudgee Beach, Brisbane } \\
27^{\circ} 21^{\prime} 3^{\prime \prime} \mathrm{S} 153^{\circ} 6^{\prime} 23^{\prime \prime} \mathrm{E}\end{array}$ & Tidal marine & КT893845 \\
\hline Navicula sp. NB1_2 & $\begin{array}{l}\text { Nudgee Beach, Brisbane } \\
27^{\circ} 21^{\prime} 3^{\prime \prime} \mathrm{S} 153^{\circ} 6^{\prime} 23^{\prime \prime} \mathrm{E}\end{array}$ & Tidal marine & KT893846 \\
\hline Chaetoceros sp. NB1_9 & $\begin{array}{l}\text { Nudgee Beach, Brisbane } \\
27^{\circ} 21^{\prime} 3^{\prime \prime} \mathrm{S} 153^{\circ} 6^{\prime} 23^{\prime \prime} \mathrm{E}\end{array}$ & Tidal marine & KT893847 \\
\hline Navicula sp. NB1_13 & $\begin{array}{l}\text { Nudgee Beach, Brisbane } \\
27^{\circ} 21^{\prime} 3^{\prime \prime} \mathrm{S} 153^{\circ} 6^{\prime} 23^{\prime \prime} \mathrm{E}\end{array}$ & Tidal marine & KT893848 \\
\hline Amphora sp. NC1_1 & $\begin{array}{l}\text { Nudgee Creek, Nudgee Beach } \\
27^{\circ} 21^{\prime} 1^{\prime \prime} \mathrm{S} 153^{\circ} 6^{\prime} 17^{\prime \prime} \mathrm{E}\end{array}$ & Tidal eutrophic marine & KT893849 \\
\hline Cylindrotheca sp. NC1_4 & $\begin{array}{l}\text { Nudgee Creek, Nudgee Beach } \\
27^{\circ} 21^{\prime} 1^{\prime \prime} \mathrm{S} 153^{\circ} 6^{\prime} 17^{\prime \prime} \mathrm{E}\end{array}$ & Tidal eutrophic marine & KT893850 \\
\hline
\end{tabular}




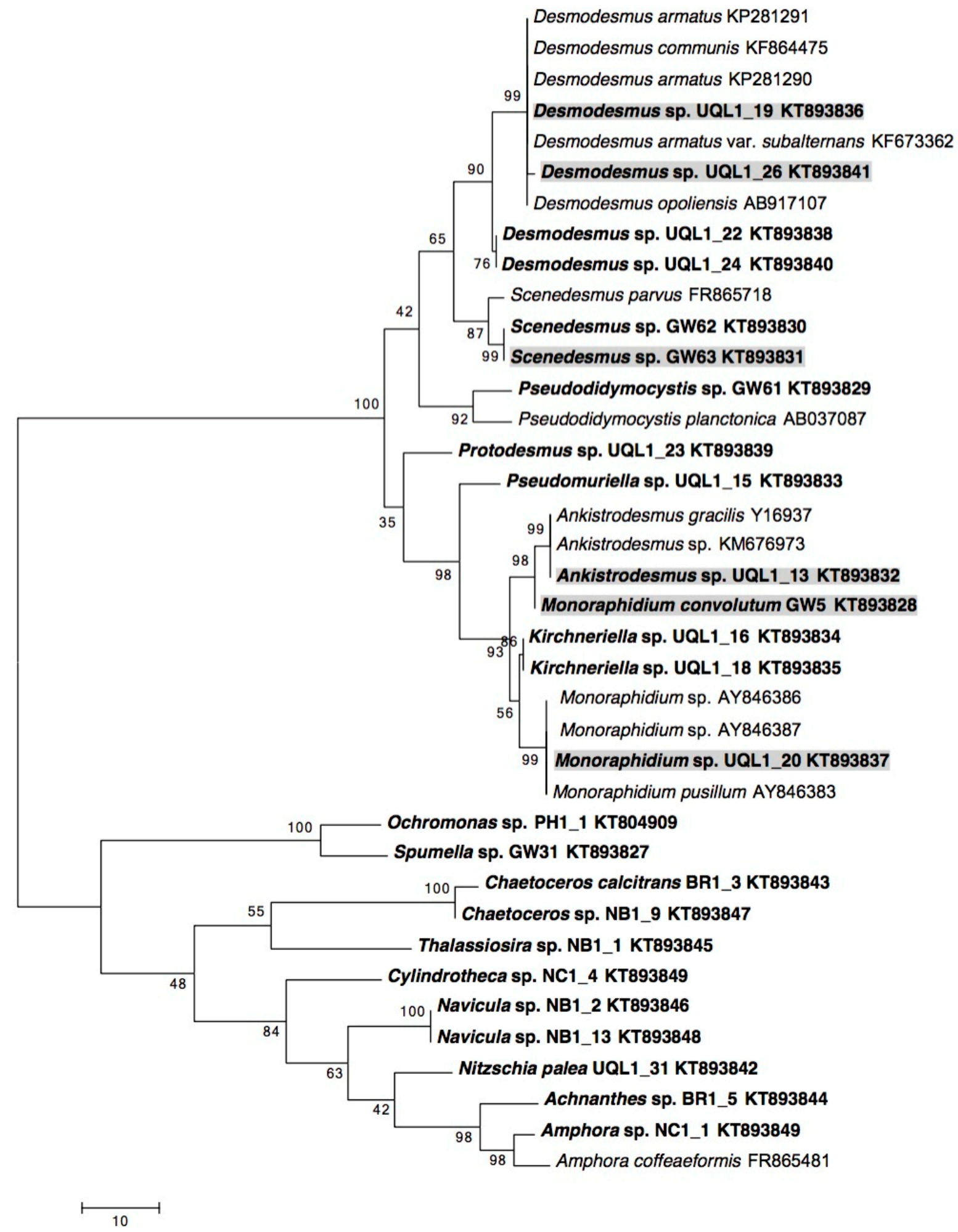

Figure 1. Phylogenetic analyses of $18 \mathrm{~S}$ rRNA gene sequences of microalgae in this study. The maximum parsimony tree is shown. Numbers near each node indicate bootstrap values (1000 replicates). Strains isolated in this study are shown in bold. Strains selected for comparative growth experiments are indicated with shading. The length of the tree is 341 with the consistency index of 0.66 , the retention index of 0.91 , and the composite index of 0.61 for all sites. 


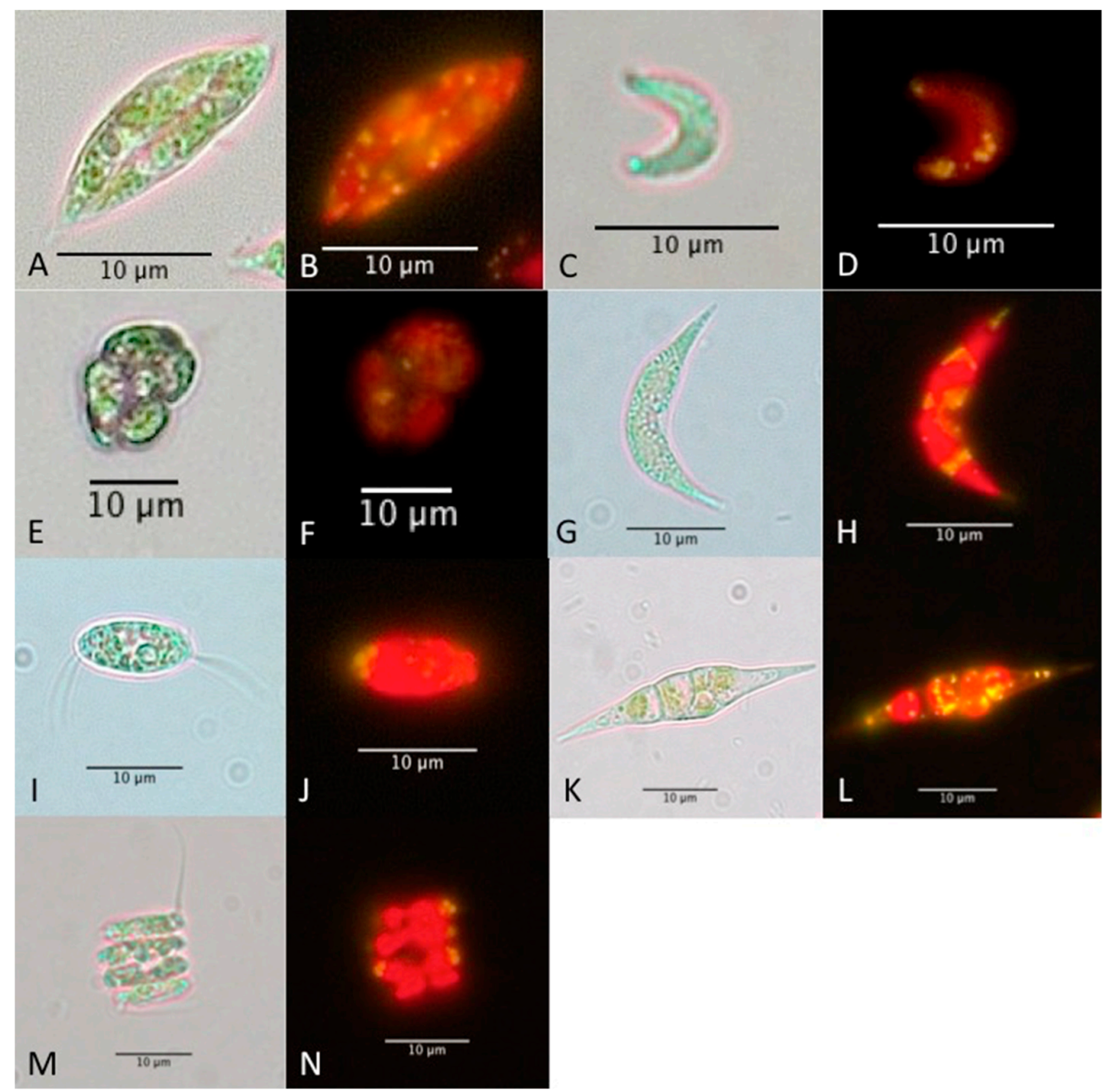

Figure 2. Images of Scenedesmus dimorphus NT8C (A,B), Monoraphidium convolutum GW5 (C,D), Scenedesmus sp. GW63 (E,F), Ankistrodesmus sp. UQL1_13 (G,H), Desmodesmus sp. UQL1_19 (I,J), Monoraphidium sp. UQL1_20 (K,L), Desmodesmus sp. UQL1_26 (M,N) under the compound microscope with bright field and epifluorescent light. Neutral lipids are shown as yellow droplets after Nile red staining, whereas chlorophyll is shown in red.

\subsection{Cultivation and Growth}

After inoculation for the standardized assay, most cultures maintained exponential growth with the exception of Scenedesmus sp. GW63, which did not grow during day 1 and resumed growth on day 2. A lag phase was observed in Monoraphidium sp. UQL1_20 on day 3, and Desmodesmus sp. UQL1_26 on day 2 and day 4. All cultures attained exponential growth in relatively homogeneous patterns till the end of the experiment (Figure 3). S. dimorphus NT8C maintained relatively the same growth rate (on average) before and after nutrient depletion. The average growth rate was slightly reduced in Ankistrodesmus sp. ULQ1_13, Desmodesmus sp. UQL1_19, Monoraphidium sp. UQL1_20 upon nutrient deprivation, and slightly increased in $M$. convolutum GW5, Scenedesmus sp. GW63 and Desmodesmus sp. UQL1_26 (Figure 3). Nutrient draw down was the fastest in S. dimorphus NT8C, with no residual nitrate detected in the medium on day 3. Nitrate in culture media was consumed by all other strains by day 5 (Figure 4). 


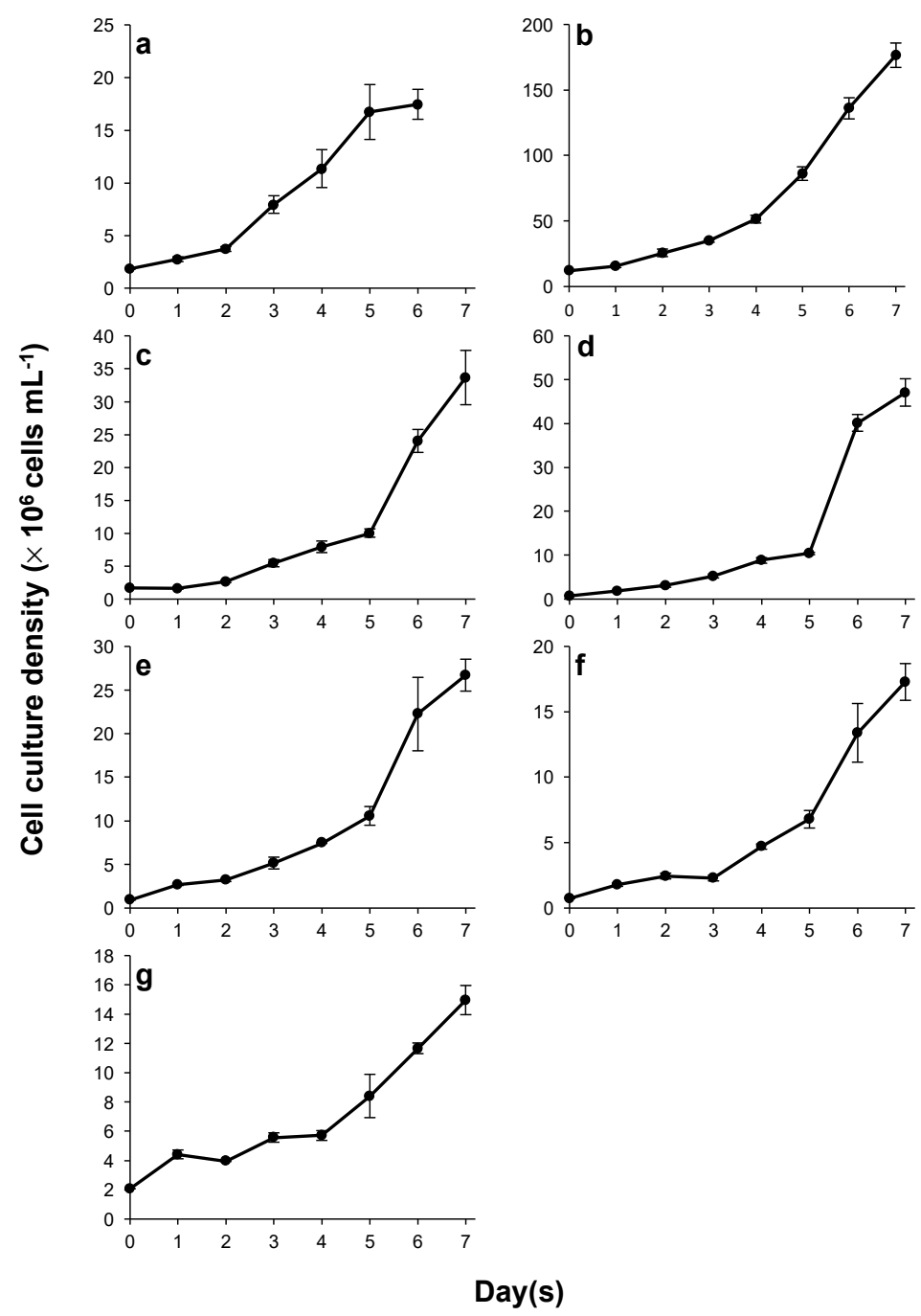

Figure 3. Growth curves of S. dimorphus NT8C (a), M. convolutum GW5 (b), Scenedesmus sp. GW63 (c), Ankistrodesmus sp. UQL1_13 (d), Desmodesmus sp. UQL1_19 (e), Monoraphidium sp. UQL1_20 (f), Desmodesmus sp. UQL1_26 (g). Shown are mean values $( \pm \mathrm{SE})$ from three separately-grown replicate cultures (six replicates for reference strain S. dimorphus NT8C).

The highest growth rate was found for Ankistrodesmus sp. UQL1_13 $\left(0.60 \mathrm{day}^{-1}\right)$, followed by Desmodesmus sp. UQL1_19 $\left(0.48 \mathrm{day}^{-1}\right)$, Monoraphidium sp. UQL1_20 $\left(0.45 \mathrm{day}^{-1}\right)$, S. dimorphus NT8C $\left(0.44\right.$ day $\left.^{-1}\right)$, and Scenedesmus sp. GW63 (0.42 day $\left.{ }^{-1}\right)$ (Table 3). The lowest growth rate was observed in Desmodesmus sp. UQL1_26 (0.28 day $\left.{ }^{-1}\right)$. Average growth rates were highly variable within the same genus apart from two Scenedesmus spp. According to growth rates, cell doubling time was the shortest in Ankistrodesmus sp. UQL1_13 (1.15 days) and the longest in Desmodesmus sp. UQL1_26 (2.45 days) (Table 3).

$M$. convolutum GW5 reached the maximum cell density (cell densityMax) of $176.50 \times 10^{6}$ cells $\mathrm{mL}^{-1}$, while Desmodesmus sp. UQL1_26 reached the minimum cell density of $14.96 \times 10^{6}$ cells $\mathrm{mL}^{-1}$ among the seven studied strains (Table 3). S. dimorphus NT8C was the highest biomass producer when grown till late $\log$ phase $\left(0.17 \mathrm{~g} \mathrm{~L}^{-1}\right.$ day $\left.^{-1}\right)$ and a high biomass producer during the whole period of the growth experiment $\left(0.24 \mathrm{~g} \mathrm{~L}^{-1}\right.$ day $\left.^{-1}\right)$ and nutrient deprivation phase $\left(0.37 \mathrm{~g} \mathrm{~L}^{-1} \mathrm{day}^{-1}\right)$. However, Scenedesmus sp. GW63 became the most productive strain with its high average biomass productivity over the duration of the growth experiment $\left(0.27 \mathrm{~g} \mathrm{~L}^{-1}\right.$ day $\left.^{-1}\right)$ and its biomass productivity over the nutrient depleted period $\left(0.37 \mathrm{~g} \mathrm{~L}^{-1}\right.$ day $\left.^{-1}\right)$. The fast-growing strain Ankistrodesmus sp. UQL1_13 showed considerable strength in producing biomass during nutrient depletion $\left(0.37 \mathrm{~g} \mathrm{~L}^{-1}\right.$ day $\left.^{-1}\right)$. Notably, algal biomass productivity achieved during the nutrient 
depleted period was higher overall compared to other growth phases; however, patterns were highly variable between species.

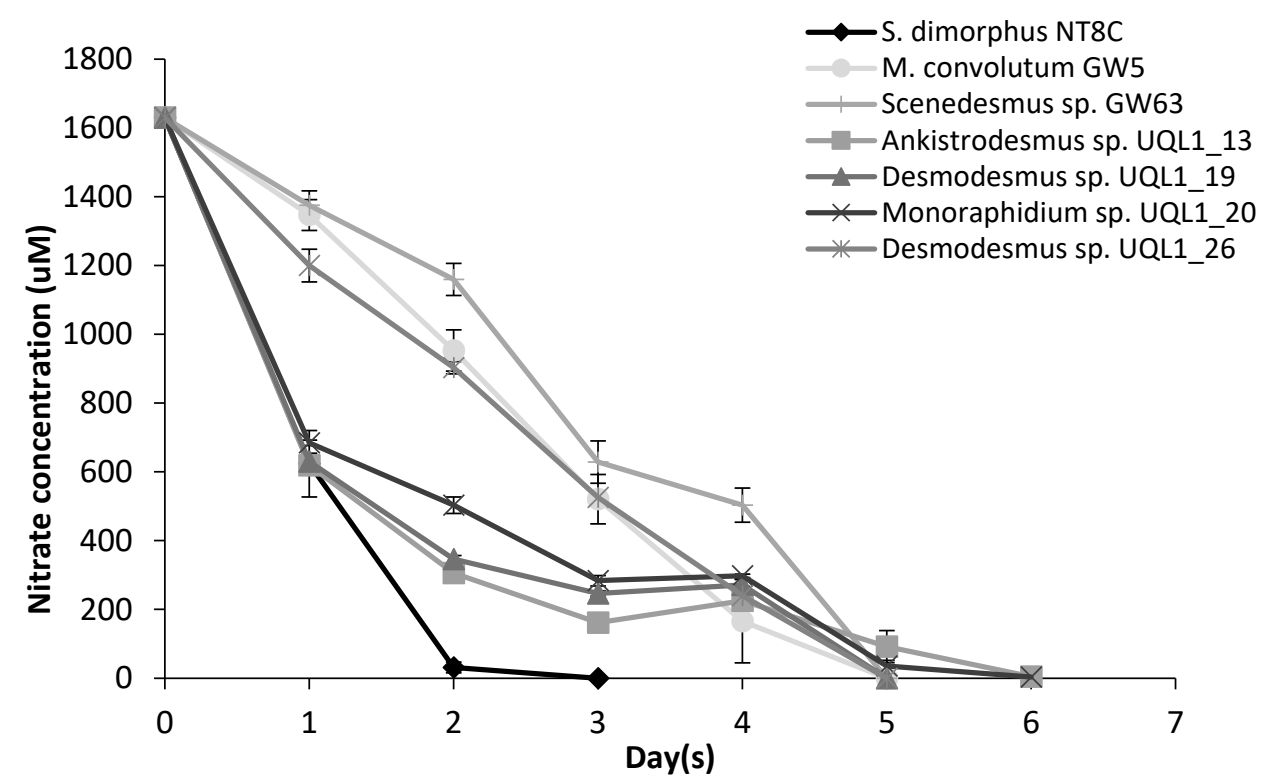

Figure 4. Nitrate usage of the seven microalgal strains used in the growth experiment. Shown are mean values $( \pm \mathrm{SE})$ from three replicates (six replicates for $S$. dimorphus NT8C). Due to the experimental error and natural variation of the method used for measuring nitrate concentration, the values less than $100 \mu \mathrm{M}$ were too low to be measured accurately.

Table 3. Growth rate, cell density, doubling time and biomass productivity analysis of seven microalgal strains during the growth experiment.

\begin{tabular}{|c|c|c|c|c|c|c|}
\hline \multirow[b]{2}{*}{ Strain } & \multirow[b]{2}{*}{$\begin{array}{c}\text { Average } \\
\text { Growth Rate }\end{array}$} & \multirow[b]{2}{*}{$\begin{array}{l}\text { Cell Density }{ }_{\max } \\
\left(\times 10^{6} \text { cells } \mathrm{mL}^{-1}\right)\end{array}$} & \multirow[b]{2}{*}{$\begin{array}{l}\text { Doubling } \\
\text { Time (days) }\end{array}$} & \multicolumn{3}{|c|}{ Biomass Productivity $\left(\mathrm{g} \mathrm{L}^{-1}\right.$ day $^{-1}$ ) } \\
\hline & & & & $\begin{array}{c}\text { Biomass } \\
\text { Productivity } \\
\text { LL } \\
\end{array}$ & $\begin{array}{c}\text { Biomass } \\
\text { Productivity } \\
\text { AVE }\end{array}$ & $\begin{array}{c}\text { Biomass } \\
\text { Productivity } \\
\text { ND } \\
\end{array}$ \\
\hline S. dimorphus NT8C & $0.44^{\mathrm{a}}$ & 22.54 & $1.59^{\mathrm{a}}$ & $0.17^{\mathrm{a}}$ & $0.24^{\mathrm{a}}$ & $0.37^{\mathrm{a}}$ \\
\hline M. convolutum GW5 & $0.38^{\mathrm{a}}$ & 176.50 & $1.81^{\mathrm{a}}$ & $0.10^{\mathrm{b}}$ & $0.21^{\mathrm{a}, \mathrm{b}}$ & $0.35^{\mathrm{a}, \mathrm{b}, *}$ \\
\hline Scenedesmus sp. GW63 & $0.42^{\mathrm{a}}$ & 33.67 & $1.64^{\mathrm{a}}$ & $0.14^{\mathrm{a}}$ & $0.27^{\mathrm{a}}$ & $0.44^{\mathrm{a}}$ \\
\hline $\begin{array}{c}\text { Ankistrodesmus sp. } \\
\text { UQL1_13 }\end{array}$ & $0.60^{\mathrm{b}}$ & 47.08 & $1.15^{\mathrm{b}}$ & $0.09^{b}$ & $0.22^{\mathrm{a}}$ & $0.37^{\mathrm{a}}$ \\
\hline $\begin{array}{c}\text { Desmodesmus sp. } \\
\text { UQL1_19 }\end{array}$ & $0.48^{\mathrm{a}, \mathrm{b}}$ & 26.71 & $1.44^{\mathrm{a}, \mathrm{b}}$ & $0.10^{\mathrm{b}}$ & $0.19^{\mathrm{b}}$ & $0.30^{\mathrm{b}}$ \\
\hline $\begin{array}{l}\text { Monoraphīium sp. } \\
\text { UQL1_20 }\end{array}$ & $0.45^{\mathrm{a}}$ & 17.29 & $1.54^{\mathrm{a}}$ & $0.09^{b}$ & $0.16^{\mathrm{b}}$ & $0.25^{b}$ \\
\hline $\begin{array}{c}\text { Desmodesmus sp. } \\
\text { UQL1_26 }\end{array}$ & $0.28^{c}$ & 14.96 & $2.45^{\mathrm{c}}$ & $0.10^{\mathrm{b}}$ & $0.19^{b}$ & $0.31^{\mathrm{b}}$ \\
\hline
\end{tabular}

Biomass productivity ${ }_{L L}$-biomass productivity at the late log phase, Biomass productivity ${ }_{A V E}$-biomass productivity on average of the total growth experiment period, Biomass productivity ${ }_{N D}$-biomass productivity at the nutrient depletion period. Different small letters indicate significant $(p<0.05)$ differences based on ANOVA followed by Tukey's test. *Value was underestimated due to biomass loss in centrifugation during harvesting.

\subsection{Fatty Acid Content and Composition}

The content of TFA determined from GC-MS analyses varied markedly between strains and ranged from 11.7 to $15.9 \%$ DW (Table 4). Monoraphidium sp. UQL1_20 had the highest content of TFA (15.9\% DW), followed by Ankistrodesmus sp. UQL1_13 (14.9\% DW), while Desmodesmus sp. UQL1_26 (11.7\% DW) and S. dimorphus NT8C (11.8\% DW) had the lowest content of TFA. The proportion of SFA ranged from 21 to $31.8 \%$ of TFA across all strains with C16:0 (palmitic acid, 17.9-25.7\% of TFA) being the most abundant SFA. The proportion of MUFA was between 28.5 and $35.4 \%$ of TFA, dominated by C18:1(n-9) (oleic acid, 26.4-32.7\% of TFA). All strains had high proportions of PUFA (33-41.6\% of TFA), dominated by C18:3(n-3) ( $\alpha$-linolenic acid, ALA, 11.4-20\% of TFA). No C20:5(n-3) (eicosapentaenoic acid, EPA) and C22:6(n-3) (docosahexaenoic acid, DHA) higher than the 
cut-off of $1 \%$ were found in the algae examined. The proportion of omega-3 PUFA of TFA (22-31.2\%) was larger than that of omega-6 PUFA (7.9-12.8\%), reflected by low n-6/n-3 ratios (0.3-0.6). While the types of FA present in the examined strains were essentially homogeneous, there was variation in the content and composition of FA. In a similar manner, there was also distinct variation in TFA productivity, which ranged between 22.3 and $32.6 \mathrm{mg} \mathrm{L}^{-1}$ day $^{-1}$, with Scenedesmus sp. GW63 having the highest and Desmodesmus sp. UQL1_26 having the lowest TFA productivity.

Table 4. Fatty acid composition in \% of TFA, TFA content (\% DW), and TFA productivity (mg L ${ }^{-1}$ day $^{-1}$ ) of seven microalgal strains used in this study.

\begin{tabular}{|c|c|c|c|c|c|c|c|c|c|c|c|c|c|c|c|c|c|c|c|c|c|}
\hline \multirow{2}{*}{$\begin{array}{c}\text { Fatty Acid } \\
\text { C } 14: 0\end{array}$} & \multicolumn{3}{|c|}{ S. dimorphus } & \multicolumn{3}{|c|}{$\begin{array}{c}\text { M. convolutum } \\
\text { GW5 }\end{array}$} & \multicolumn{3}{|c|}{$\begin{array}{l}\text { Scenedesmus } \\
\text { sp. GW63 }\end{array}$} & \multicolumn{3}{|c|}{$\begin{array}{l}\text { Ankistrodesmus } \\
\text { sp. UQL1_13 }\end{array}$} & \multicolumn{3}{|c|}{$\begin{array}{c}\text { Desmodesmus } \\
\text { sp. UQL1_19 }\end{array}$} & \multicolumn{3}{|c|}{$\begin{array}{l}\text { Monoraphidium } \\
\text { sp. UQL1_20 }\end{array}$} & \multicolumn{3}{|c|}{$\begin{array}{l}\text { Desmodesmus } \\
\text { sp. UQL1_26 }\end{array}$} \\
\hline & 0.3 & \pm & 0.0 & 0.4 & \pm & 0.0 & 0.2 & \pm & 0.0 & 0.3 & \pm & 0.0 & 0.3 & \pm & 0.0 & 0.3 & \pm & 0.0 & 0.3 & \pm & 0.0 \\
\hline C14:1 & 0.3 & \pm & 0.0 & 0.4 & \pm & 0.0 & 0.2 & \pm & 0.0 & 0.3 & \pm & 0.0 & 0.3 & \pm & 0.0 & 0.3 & \pm & 0.0 & 0.3 & \pm & 0.0 \\
\hline C15:0 & 0.1 & \pm & 0.0 & 0.1 & \pm & 0.0 & 0.1 & \pm & 0.0 & 0.1 & \pm & 0.0 & 0.1 & \pm & 0.0 & 0.1 & \pm & 0.0 & 0.1 & \pm & 0.0 \\
\hline C16:0 & 20.4 & \pm & 0.3 & 21.9 & \pm & 0.4 & 17.9 & \pm & 0.4 & 25.7 & \pm & 0.3 & 25.7 & \pm & 0.1 & 18.8 & \pm & 0.4 & 21.4 & \pm & 0.5 \\
\hline C16:1(n-9) & 1.1 & \pm & 0.0 & 0.5 & \pm & 0.0 & 1.2 & \pm & 0.0 & 0.7 & \pm & 0.0 & 0.6 & \pm & 0.0 & 0.7 & \pm & 0.1 & 1.4 & \pm & 0.1 \\
\hline C16:1(n-7) & 0.2 & \pm & 0.0 & 0.3 & \pm & 0.0 & 0.3 & \pm & 0.0 & 0.2 & \pm & 0.0 & 0.4 & \pm & 0.1 & 0.5 & \pm & 0.1 & 0.3 & \pm & 0.0 \\
\hline C16:2(n-6) & 0.8 & \pm & 0.0 & 0.6 & \pm & 0.0 & 0.7 & \pm & 0.0 & 1.0 & \pm & 0.0 & 0.6 & \pm & 0.0 & 0.7 & \pm & 0.0 & 1.1 & \pm & 0.0 \\
\hline$C 16: 3(n-3)$ & 4.2 & \pm & 0.1 & 1.3 & \pm & 0.0 & 3.2 & \pm & 0.2 & 2.3 & \pm & 0.1 & 3.6 & \pm & 0.1 & 3.1 & \pm & 0.0 & 5.2 & \pm & 0.2 \\
\hline$C 16: 4(n-3)$ & 5.6 & \pm & 0.3 & 6.4 & \pm & 0.3 & 2.7 & \pm & 0.2 & 4.1 & \pm & 0.2 & 3.7 & \pm & 0.1 & 5.6 & \pm & 0.5 & 3.2 & \pm & 0.1 \\
\hline C17:0 & 0.2 & \pm & 0.0 & 1.3 & \pm & 0.1 & 0.1 & \pm & 0.0 & 1.8 & \pm & 0.0 & 0.4 & \pm & 0.0 & 0.4 & \pm & 0.0 & 0.3 & \pm & 0.0 \\
\hline C17:1(n-7) & 0.1 & \pm & 0.0 & 0.1 & \pm & 0.0 & 0.2 & \pm & 0.0 & 0.1 & \pm & 0.0 & 0.3 & \pm & 0.0 & 0.1 & \pm & 0.0 & 0.2 & \pm & 0.0 \\
\hline C18:0 & 2.5 & \pm & 0.2 & 1.6 & \pm & 0.1 & 2.2 & \pm & 0.2 & 2.7 & \pm & 0.0 & 3.5 & \pm & 0.3 & 2.2 & \pm & 0.2 & 2.6 & \pm & 0.2 \\
\hline C18:1(n-9) & 27.9 & \pm & 1.3 & 28.5 & \pm & 1.1 & 30.2 & \pm & 1.0 & 26.4 & \pm & 0.2 & 28.4 & \pm & 0.3 & 32.7 & \pm & 2.2 & 30.6 & \pm & 0.4 \\
\hline C18:2(n-6) & 9.0 & \pm & 0.4 & 7.0 & \pm & 0.3 & 10.1 & \pm & 0.3 & 8.9 & \pm & 0.2 & 6.8 & \pm & 0.1 & 7.3 & \pm & 0.2 & 10.2 & \pm & 0.1 \\
\hline C18:3(n-6) & 0.6 & $\overline{ \pm}$ & 0.0 & 0.2 & \pm & 0.0 & 0.1 & \pm & 0.0 & 0.2 & \pm & 0.0 & 1.1 & \pm & 0.0 & 0.5 & \pm & 0.1 & 1.4 & \pm & 0.1 \\
\hline$C 18: 3(n-3)$ & 19.3 & \pm & 0.4 & 16.5 & \pm & 0.6 & 20.0 & \pm & 0.8 & 14.6 & \pm & 0.3 & 14.9 & \pm & 0.2 & 15.1 & \pm & 0.5 & 11.4 & \pm & 0.0 \\
\hline C18:4(n-3) & 2.2 & \pm & 0.1 & 3.4 & \pm & 0.2 & 2.5 & \pm & 0.2 & 3.4 & \pm & 0.1 & 2.2 & \pm & 0.0 & 3.6 & \pm & 0.3 & 2.2 & \pm & 0.1 \\
\hline C20:0 & 0.1 & \pm & 0.0 & 0.2 & \pm & 0.0 & 0.2 & \pm & 0.0 & 0.2 & \pm & 0.0 & 0.2 & \pm & 0.0 & 0.1 & \pm & 0.0 & 0.2 & \pm & 0.0 \\
\hline C20:1(n-9) & 0.3 & \pm & 0.0 & 0.8 & \pm & 0.0 & 2.1 & \pm & 0.2 & 0.7 & \pm & 0.0 & 0.4 & \pm & 0.0 & 1.0 & \pm & 0.1 & 0.3 & \pm & 0.0 \\
\hline C20:2(n-6) & - & & & 0.1 & \pm & 0.0 & 0.1 & \pm & 0.0 & - & & & - & & & - & & & 0.1 & \pm & 0.0 \\
\hline$C 20: 3(n-3)$ & - & & & - & & & 0.1 & \pm & 0.0 & - & & & - & & & - & & & - & & \\
\hline C20:5(n-3) & - & & & - & & & - & & & - & & & - & & & - & & & - & & \\
\hline C22:0 & 0.2 & \pm & 0.0 & 0.9 & \pm & 0.0 & 0.3 & \pm & 0.0 & 0.2 & \pm & 0.0 & 0.2 & \pm & 0.0 & 0.3 & \pm & 0.1 & 0.3 & \pm & 0.0 \\
\hline C22:1(n-9) & - & & & 0.2 & \pm & 0.0 & 0.2 & \pm & 0.0 & 0.1 & \pm & 0.0 & 0.1 & \pm & 0.0 & 0.1 & \pm & 0.0 & 0.1 & \pm & 0.0 \\
\hline C22:6(n-3) & - & & & - & & & - & & & - & & & - & & & - & & & - & & \\
\hline C $24: 0$ & 0.2 & \pm & 0.0 & 1.0 & \pm & 0.1 & - & & & 0.8 & \pm & 0.1 & 0.1 & \pm & 0.0 & 0.7 & \pm & 0.0 & 0.1 & \pm & 0.0 \\
\hline $\begin{array}{l}\text { Other fatty } \\
\text { acids }\end{array}$ & 4.7 & \pm & 0.5 & 6.2 & \pm & 0.3 & 5.0 & \pm & 0.6 & 5.2 & \pm & 0.6 & 6.1 & \pm & 0.4 & 5.8 & \pm & 0.9 & 6.8 & \pm & 0.7 \\
\hline Total SFA & 23.8 & \pm & 0.4 & 27.4 & \pm & 0.5 & 21.0 & \pm & 0.6 & 31.8 & \pm & 0.2 & 30.5 & \pm & 0.3 & 22.8 & \pm & 0.4 & 25.2 & \pm & 0.7 \\
\hline Total MUFA & 30.0 & \pm & 1.2 & 30.9 & \pm & 1.1 & 34.5 & \pm & 0.9 & 28.5 & \pm & 0.3 & 30.3 & \pm & 0.3 & 35.4 & \pm & 2.1 & 33.3 & \pm & 0.3 \\
\hline Total PUFA & 41.6 & \pm & 1.1 & 35.4 & \pm & 1.4 & 39.5 & \pm & 1.4 & 34.5 & \pm & 0.8 & 33.0 & \pm & 0.2 & 36.0 & \pm & 1.6 & 34.8 & \pm & 0.3 \\
\hline$\omega-3$ PUFA & 31.2 & \pm & 0.8 & 27.5 & \pm & 1.1 & 28.5 & \pm & 1.2 & 24.4 & \pm & 0.6 & 24.4 & \pm & 0.1 & 27.4 & \pm & 1.3 & 22.0 & \pm & 0.2 \\
\hline$\omega-6$ PUFA & 10.3 & \pm & 0.4 & 7.9 & \pm & 0.3 & 11.0 & \pm & 0.3 & 10.1 & \pm & 0.3 & 8.6 & \pm & 0.1 & 8.6 & \pm & 0.3 & 12.8 & \pm & 0.2 \\
\hline$\omega-6 / \omega-3$ & 0.3 & \pm & 0.0 & 0.3 & \pm & 0.0 & 0.4 & \pm & 0.0 & 0.4 & \pm & 0.0 & 0.4 & \pm & 0.0 & 0.3 & \pm & 0.0 & 0.6 & \pm & 0.0 \\
\hline $\begin{array}{c}\text { TFA (\% DW) } \\
\text { TFA }\end{array}$ & 11.8 & \pm & 0.3 & 13.4 & \pm & 0.6 & 12.1 & \pm & 1.0 & 14.9 & \pm & 1.4 & 12.8 & \pm & 0.9 & 15.9 & \pm & 0.6 & 11.7 & \pm & 0.5 \\
\hline $\begin{array}{l}\text { productivity } \\
\left(\mathrm{mg} \mathrm{L}^{-1} \text { day }^{-1}\right)\end{array}$ & 30.8 & \pm & 2.6 & 28.0 & \pm & 1.1 & 32.6 & \pm & 4.2 & 32.2 & \pm & 3.1 & 23.6 & \pm & 1.4 & 25.2 & \pm & 3.4 & 22.3 & \pm & 1.3 \\
\hline
\end{tabular}

SFA saturated fatty acids, MUFA monounsaturated fatty acids, PUFA polyunsaturated fatty acids, TFA total fatty acids, $D W$ dry weight. Shown are mean values $( \pm$ SE) from three replicates.

\subsection{Total Protein Content}

The crude protein content ranged from 15.3 to $33.4 \%$ DW across all tested strains (Figure 5). The highest protein content was found in two Desmodesmus spp. UQL1_26 (33.4\% DW) and UQL1_19 (33.1\% DW), followed by Monoraphidium sp. UQL1_20 (32.9\% DW) and Ankistrodesmus sp. UQL1_13 (31.8\% DW), whereas the lowest protein content was found in two Scenedesmus strains, S. dimorphus NT8C (17.8\% DW) and Scenedesmus sp. GW63 (15.3\% DW), respectively. Desmodesmus spp. UQL1_26 protein productivity was approximately $61.0 \%$ higher than Scenedesmus sp. GW63. 


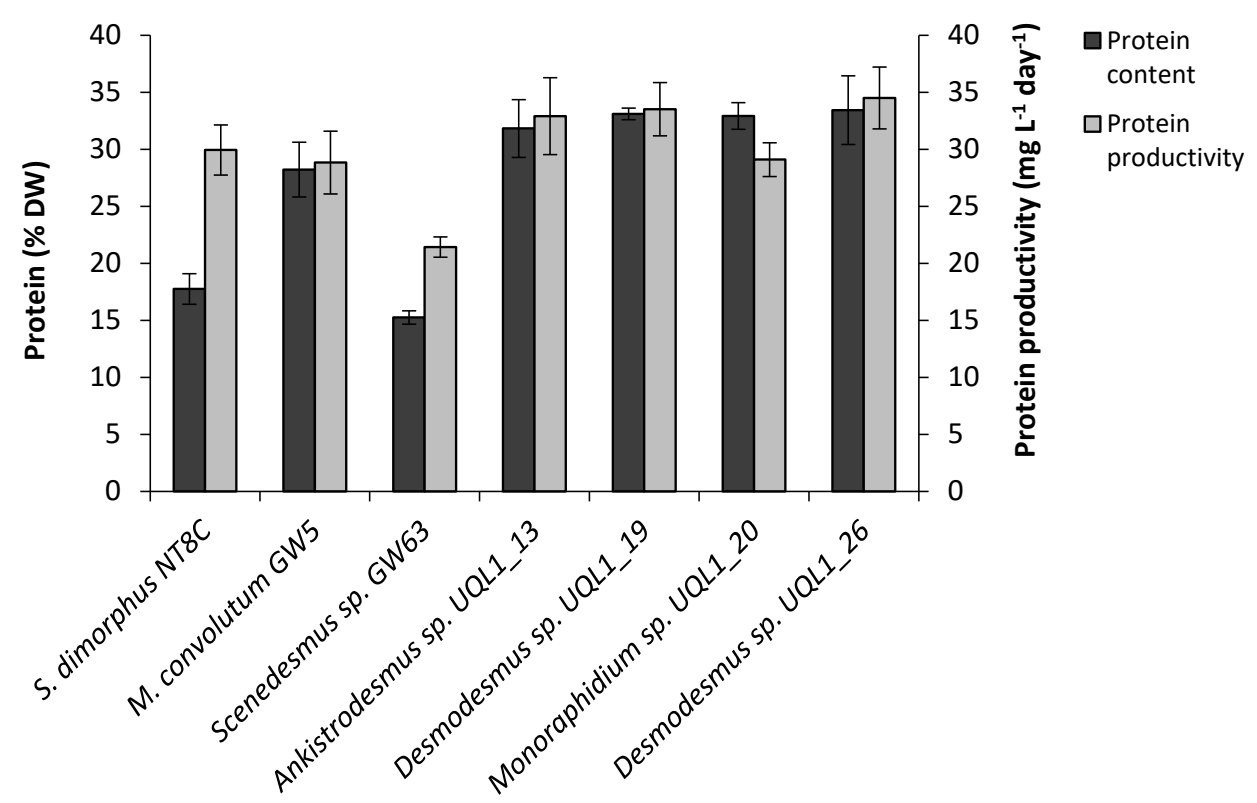

Figure 5. Total protein content (\% DW) and protein productivity $\left(\mathrm{mg} \mathrm{L}^{-1} \mathrm{day}^{-1}\right)$ of the seven microalgal strains used in this study. Shown are mean values $( \pm \mathrm{SE})$ from three replicate cultures (six replicates for S. dimorphus NT8C).

\subsection{Total Carotenoid Content}

Striking variation (ranging from 0.1 to $8.1 \mathrm{mg} \mathrm{g}^{-1} \mathrm{DW}$ ) of the total carotenoid content was found across the studied strains (Figure 6). M. convolutum GW5 accumulated the largest amount of carotenoids ( $\left.8.1 \mathrm{mg} \mathrm{g}^{-1} \mathrm{DW}\right)$, followed by Ankistrodesmus sp. UQL1_13 (6.0 $\mathrm{mg} \mathrm{g}^{-1} \mathrm{DW}$ ) and Monoraphidium sp. UQL1_20 (4.9 $\left.\mathrm{mg} \mathrm{g}^{-1} \mathrm{DW}\right)$. Scenedesmus sp. GW63 had the lowest content of carotenoids $\left(0.1 \mathrm{mg} \mathrm{g}^{-1} \mathrm{DW}\right)$, followed by Desmodesmus sp. UQL1_26 (1.0 $\left.\mathrm{mg} \mathrm{g}^{-1} \mathrm{DW}\right)$. M. convolutum GW5 had the highest carotenoid productivity $\left(0.8 \mathrm{mg} \mathrm{L}^{-1}\right.$ day $\left.^{-1}\right)$, which was up to $694.6 \%$ greater than that of Scenedesmus sp. GW63 and Desmodesmus sp. UQL1_26, and 106.0\% greater than that of S. dimorphus NT8C.

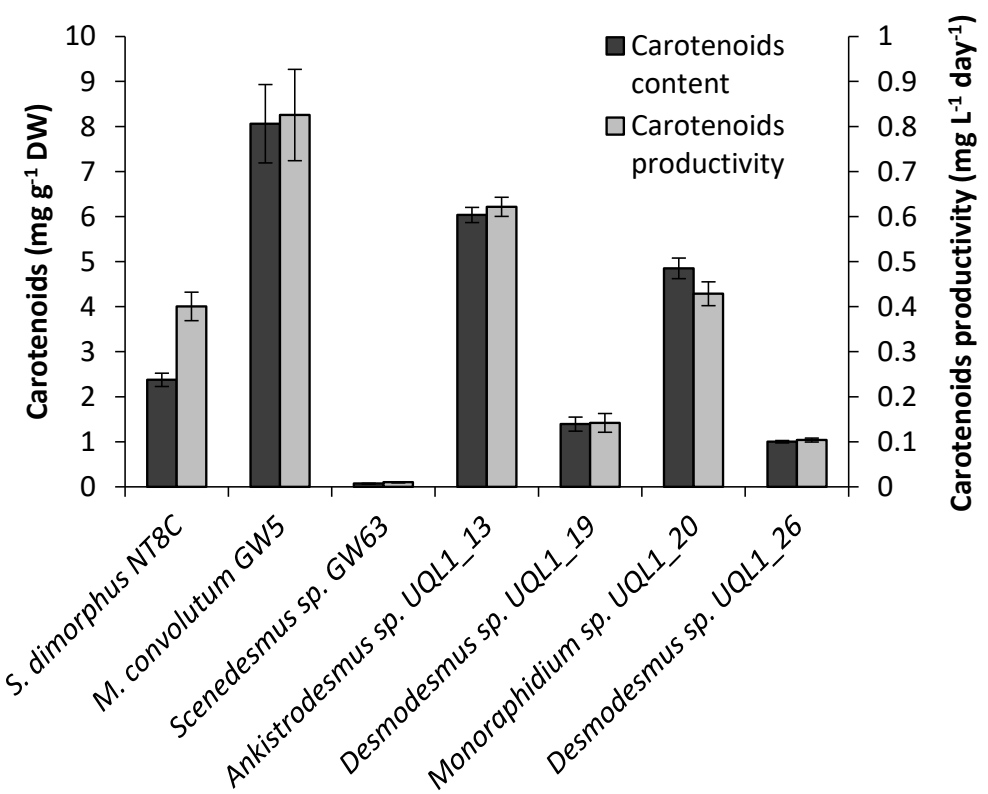

Figure 6. Total carotenoid content $\left(\mathrm{mg} \mathrm{g}^{-1} \mathrm{DW}\right)$ and carotenoid productivity $\left(\mathrm{mg} \mathrm{L}^{-1}\right.$ day $\left.^{-1}\right)$ of the seven microalgal strains used in this study. Shown are mean values $( \pm S E)$ from three replicate cultures (six replicates for $S$. dimorphus NT8C). 


\section{Discussion}

\subsection{Sample Collection, Isolation, Identification and Selection of Microalgal Strains}

Selecting suitable local microalgal strains is a fundamental step for achieving reliable and feasible commercial production of bioproducts. It requires algae to produce the desired biocompounds under the local environmental conditions of which large-scale cultivation is envisaged [44]. Thus, the habitat-centered collection strategy [45] was adopted in the hope that these algae are better adapted and resilient to local conditions. In the present study, microalgae were collected from local sites with suboptimal conditions, and subsequently isolated and identified. The choice of these sites was driven by the notion that aquatic environments with fluctuating and at times extreme conditions provide the best habitats for both, fast-growing, opportunistic as well as resilient microalgae. In our study, variable conditions included fluctuating salinity, temperature, and nutrient availability. A rapid isolation protocol was combined with initial screening and standardized productivity assays that enable direct comparisons between strains as well as benchmarking to previously characterized strains (Scenedesmus dimorphus NT8C in our study). In this assay, parameters, such as light irradiation, cultivation time and temperature were kept constant. While this led to the rapid identification of local high-performing strains for various applications, it should be considered that the standardized assay is not optimized for each strain. It therefore serves as a decision tool to select microalgae for large-scale cultivation, rather than providing definite answers on which strains can be used commercially under fully-optimized conditions. Growth optimization, large-scale cultivation and stimulation of biosynthesis of various valuable compounds, such as carotenoids, will still be required. Nevertheless, the most critical issues (rapid growth in commercial fertilizer, high compound productivity, and cost-effective harvesting by settling) have been addressed by the current study.

Partial sequence of the 18S rRNA gene is a widely accepted and commonly used approach in microalgae identification [46-49]. However, the analyses of sequence, phylogeny and morphology were inconclusive to identify all microalgal strains to the species level in this study. Resolution and reconstruction of relationships at the species level is rather limited due to the high conservation of the $18 \mathrm{~S}$ rRNA gene $[43,48,50]$, and the fact that small subunit ribosomal (SSU) RNA often underestimates the true number of species in planktonic microalgae $[48,50]$. Although the majority of microalgae taxa are described based on morphological taxonomy, species identification remains challenging, due to the difficulty of observing specific morphological characteristics and the morphological variations at different life stages [51]. In addition, phenotypic plasticity caused by environmental conditions [52] and genotypic differences have been reported in many microalgae [53,54]. The studied taxa Monoraphidium, Ankistrodesmus and Kirchneriella formed a monophyletic clade within Chlorophyceae, but interestingly, two Monoraphidium spp., (M. convolutum GW5 and Monoraphidium sp. UQL1_20) did not form a distinct clade. This finding supports the view of Fawley et al. [55], and Krienitz et al. [47,56], where species of the family Selenastraceae under existing taxonomic criteria display a polyphyletic nature. Further analyses using a combination of morphological characteristics, including ultrastructure $[46,47,51]$ and DNA sequence including the internal transcribed spacer 2 (ITS2) rDNA, which has higher substitution rates in comparing with $18 \mathrm{~S}$ rRNA gene $[43,47,48,50,56]$, are required for discrimination of algal species.

\subsection{Cultivation and Growth}

Rapid growth rate and high biomass productivity are key desirable characteristics in selecting microalgae for cost-effective commercial cultivation [44]. The standard growth experiment under unoptimized laboratory conditions [2] was used to establish and compare growth rates, biomass productivity, and biochemical contents of seven microalgal strains in this study. Overall, the average growth rate (ranged from 0.28 to 0.60 day $^{-1}$ ) was comparable to, or greater than those recorded in other studies [57-60], aside from M. convolutum [61] and S. dimorphus NT8C [34]. S. dimorphus NT8C is a fast growing and easily harvested alga with a wide range of temperature tolerance. The average growth 
rate of Ankistrodesmus sp. UQL1_13, Desmodesmus sp. UQL1_19, and Monoraphidium sp. UQL1_20 was found to be higher than S. dimorphus NT8C. However, as shown in this study and previous literature [62-64], fast growth rates do not necessarily represent high biomass productivities. The largest biomass producer Scenedesmus sp. GW63 was shown to produce $18.9 \%$ more biomass than $S$. dimorphus NT8C. The highest biomass productivity ( 0.25 to $0.44 \mathrm{~g} \mathrm{~L}^{-1}$ day $^{-1}$ ) was achieved during nutrient depletion where high biomass density was accumulated, despite the lack of $\mathrm{CO}_{2}$ supply, prolonged photoperiods, and high nitrogen availability. This is in the median or upper range compared to the estimated average microalgae biomass productivity of $0.18 \mathrm{~g} \mathrm{~L}^{-1}$ day $^{-1}$ found by Griffiths and Harrison [35] and Rodolfi et al. [3]; previous studies of the same species ranged from 0.01 to $0.26 \mathrm{~g} \mathrm{~L}^{-1}$ day $^{-1}[3,14,34,59,60,65]$, and current commercialized freshwater species Chlorella vulgaris ranged from 0.01 to $0.73 \mathrm{~g} \mathrm{~L}^{-1}$ day $^{-1}[3,14,28,35,64]$, and Spirulina maxima ranged from 0.21 to $0.25 \mathrm{~g} \mathrm{~L}^{-1}$ day $^{-1}[14,66]$.

Genotypic differences and phenotypic plasticity between strains and species may be causing variation in algae growth [67]. In fact, it is important to consider that cultivation conditions such as light, nutrients, temperature, growth phase, and even culture senescence (aging) have substantial impact on growth and biochemical content of algae [68,69]. Nitrate concentration used in commercial agricultural fertilizer medium in this study was low compared to other commonly used culturing media for green algae such as BBM (Bold's Basal Medium, [70]) and BG-11 [71]. Increased initial nitrogen concentrations have been associated with increases in growth rate $[2,72,73]$. Light intensity is not likely to be a limiting factor for growth and biomass production at a small scale when cell densities are low [2] and individual cells receive the optimal irradiance [74]. Nevertheless, the LED lights used in this study are more effective in energy conversion of photosynthesis and therefore might have increased algae growth rate and biomass productivity [68].

\subsection{Fatty Acid Content and Composition}

Identifying the content and composition of fatty acids are critical for evaluating the potential of microalgae for human and animal nutrition $[75,76]$. The overall TFA content of the examined algae (11.7 to $15.9 \%$ DW) was higher than in the commercially important species Spirulina platensis (4.8\% DW) [76] and certain strains of C. vulgaris (6.1-7.6\% DW) [27,76], aquaculture feed species Chaetoceros muelleri (3.5-5.9\% DW) [2,77], Isochrysis sp. (3.9-4.0\% DW) $[2,78]$, Pavlova salina (1.2-9.9\% DW) [2,77], and the oleaginous alga Botryococcus braunii (5.9\% DW) [64], but lower than Nannochloropsis oculata (26.7\% DW) [27].

Overall, the investigated strains had fatty acid profiles characterized by relative low proportions of SFA (21.0-31.8\% of TFA) and MUFA (28.5-35.4\% of TFA) and high proportions of PUFA (33.0-41.6\% of TFA). The dominant fatty acids were C16:0, C18:1(n-9) and C18:3(n-3) which is typical for green freshwater algae [69]. The investigated strains also had moderate or relative high proportions of omega-3 PUFA (22.0-31.2\% of TFA) compared to other species such as Scenedesmus quadricauda (5.4\% of TFA) [26], C. vulgaris (26.1\% of TFA) [76], but lower than C. muelleri (32.4\% of TFA) and P. salina (61.3\% of TFA) [77]. The predominant omega-3 PUFA was ALA C18:3(n-3) which is considered essential for human nutrition and has benefits for cardiovascular diseases, liver function and can redistribute body fat in animals [79]. Furthermore, the here investigated microalgae had extremely low $\mathrm{n}-6 / \mathrm{n}-3$ ratios $(0.3-0.6)$, which makes them ideal for health and nutrition, as the typical Western diet is characterized by too high $n-6 / n-3$ ratios $[80,81]$ and therefore has been associated with cancer, and cardiovascular, inflammatory and autoimmune diseases [82]. While ALA is a precursor for EPA and DHA [83], the synthesis efficiency in animals and humans is generally low and additional intake of EPA and DHA is recommended [84]. Overall, the high contents of PUFA, and specifically omega-3 PUFA with associated low n-6/n-3 ratios and coupled with relatively low contents of SFA found in seven microalgae in this study are ideal for human and animal nutrition. However, the fatty acid content and composition of microalgae varied between species and strains, and these can also be strongly influenced by culture conditions such as light, nutrients, temperature and growth phase [69]. Nitrogen 
limitation is the major stimulus of FA accumulation and composition [69]. While this may increase the total FA content by increasing the SFA and MUFA content [3], the reduction in biomass productivity [3] and the PUFA content might not be desirable for omega-3 PUFA production [2].

While the content of TFA and the FA compositions are important selection criteria for oil-producing microalgae, of particular importance is the biomass productivity and the associated FA productivity, as this determines the final FA production in a culture system. The highest FA productivity was found in Scenedesmus sp. GW63 (32.6 mg L $\mathrm{m}^{-1}$ day $\left.^{-1}\right)$, which not only accumulated more FA than those of Ankistrodesmus sp. UQL1_13 (32.2 $\mathrm{mg} \mathrm{L}^{-1} \mathrm{day}^{-1}$ ) and $S$. dimorphus NT8C (30.8 $\left.\mathrm{mg} \mathrm{L}^{-1} \mathrm{day}^{-1}\right)$, but also had a high quality of FA with a low SFA content and a high PUFA content. This FA productivity is in the upper range of other commercial microalgae such as C. vulgaris (12.6-15.6 $\mathrm{mg} \mathrm{L}^{-1} \mathrm{day}^{-1}$ ), Spirulina sp. (approximately $4 \mathrm{mg} \mathrm{L}^{-1} \mathrm{day}^{-1}$ ) [85], Isochrysis sp. (6.4-21.1 $\mathrm{mg} \mathrm{L}^{-1} \mathrm{day}^{-1}$, lipid productivity), and Nannochloropsis sp. (4.6-20.0 $\mathrm{mg} \mathrm{L}^{-1}$ day $^{-1}$, lipid productivity) [62]. In addition, the high content of total omega-3 PUFA (28.5\% of TFA) and the essential PUFA ALA (20.0\% of TFA), and the very low n-6/n-3 ratio (0.4) make Scenedesmus sp. GW63 a good choice for producing FA-rich biomass with high nutritional and health value for nutraceuticals, food, and livestock feed applications for species with the ability to bioconvert ALA into EPA and/or DHA. Subsequent enhancement of FA content and desired composition in this strain with special focus on omega-3 PUFA content and especially ALA content should be achieved through manipulations of culturing conditions [86].

\subsection{Total Protein Content}

Green algae have a high quantity of protein, with typical yields between 10 and $30 \%$ DW [87]. The crude protein content of microalgae evaluated in this study is within this range. The protein value of Desmodesmus sp. UQL1_26,Desmodesmus sp. UQL1_19, Monoraphidium sp. UQL1_20, Ankistrodesmus sp. UQL1_13 was found to be over 30\% DW, which was almost twice the amount of those found in S. dimorphus NT8C (17.8\% DW). Moreover, these top four protein producers exceeded the $20 \%$ DW protein supplement baseline set by the Ontario Ministry of Agriculture and Food for animal feeds [76,88]. Notably, the overall protein contents obtained in the present study were lower than those reported previously for the same species [26,34,65,76], apart from Monoraphidium sp. [89]. Not surprisingly, varied previous studies on commercial species C. vulgaris and Spirulina sp. also showed comparably lower values than the ones commonly reported $[29,76,85]$. Key cultivational attributes of microalgae that contribute to its protein production-light intensity and photoperiod [26,90], growth phase [14], nutrient availability [18]—are crucial considerations when evaluating protein content from different studies. In addition, some of the variability in protein content was driven by different analytical methods [22,76,91]. For example, the commonly used Kjeldahl method overestimates the protein content in microalgae with the nitrogen to protein conversion factor of 6.25 [22,91].

Nevertheless, protein content is a critical factor determining the nutritional value of microalgae in human diet, animal livestock feed, and aquaculture nutrition [16,92]. The world's most prominent commercial alga Spirulina is utilized in human nutrition due to its high protein content and other nutritive values, such as the presence of vitamins. It is renowned for improving several health conditions such as hyperlipidaemia, hypertension [16], anaemia, and immune function [76]. Microalgal biomass is also proven to be suitable for animal feed supplement $[15,16,21]$ and about $30 \%$ of global production is currently sold for this application [15]. It can be used as partial replacement for conventional protein such as soybean and fish meal in livestock feeds [16,21]. Overall, Desmodesmus sp. UQL1_26 has the highest potential to be used for protein production as feed and nutrition supplement, due to its high protein content (33.4\% of DW; Figure 5), productivity, and fast settling. Furthermore, it is capable of withstanding harsh environmental conditions and forms protective eight-celled colonies to avoid predation from small-sized grazers [52]. These features suggest that Desmodesmus sp. UQL1_26 is likely to be a reliable competitive 
strain when cultivated in mass outdoor open systems. To further investigate the nutritional quality of protein, the content and quantity of individual amino acids, especially essential amino acids, should be analyzed and compared to FAO/WHO guidelines [21]. Mutagenesis of promising microalgal strains can also lead to further protein contents. For example, a $60 \%$ increase in protein content (to $48.7 \%$ of DW) has been reported recently for a Chlorella vulgaris mutant with reduced chlorophyll contents when grown heterotrophically [93].

\subsection{Total Carotenoid Content}

Microalgae are also good sources of carotenoids, with an average content of 0.1 to $0.2 \%$ DW [16,21]. The overall carotenoid content of the here investigated strains $(0.1$ to $0.8 \% \mathrm{DW}$ ) are similar to, or higher than this average value, aside from Scenedesmus sp. GW63 (0.01\% DW). The carotenogenic strain M. convolutum GW5 was capable of accumulating $0.8 \% \mathrm{DW}$ carotenoids without further stress induction. This value is greater than those in commonly reported species Scenedesmus obliquus $(0.3 \% \mathrm{DW})$ and aquaculture feed species C. muelleri (0.4\% DW), Isochrysis galbana $(0.5 \% \mathrm{DW})$, Tetraselmis suecica $(0.6 \% \mathrm{DW})$, Pavlova salina $(0.5 \%$ DW) $[30,77]$, the commercial alga C. vulgaris $(0.01-0.1 \%$ DW) $[23,76]$, and even the famous $\beta$-carotene producer $D$. salina in some studies $(0.7 \% \mathrm{DW})[30]$ and the natural astaxanxin source $H$. pluvialis $(0.4 \%$ DW) [94]. However, as expected, the carotenoid content of $M$. convolutum GW5 is still considerable low compared to commercial carotenogenic $H$. pluvialis and D. salina, which are currently dominating the lucrative carotenoid market $[4,16,17]$. While these high carotenoid contents of commercial producers are usually achieved under specific stress-induced production, the microalgae presented in this study did not grow under any of the following carotenogenesis conditions: high light intensity $\left(175 \mu \mathrm{mol}\right.$ photons $\left.\mathrm{m}^{-2} \mathrm{~s}^{-1}\right)$, phosphate or sulphate starvation and salt stress $(0.8 \%$ of $\mathrm{NaCl})$ [95], which might explain their relative low values. However, stress-induced carotenogenesis is likely to reduce algae growth rates [95], biomass productivity [96,97] and therefore increases the production costs [4,17]. In addition, variation in carotenoid content and the extremely low value obtained from Scenedesmus sp. GW63 can be due to the algae cell disruption method used, the pigment-protein binding efficiency [94] and loss of pigments within time [98] in aqueous acetone extraction.

Carotenoid contents and properties, especially its antioxidant activity and pigmentation are critical measurements in determining microalgae's suitability in the food and feed industry. Carotenoid-rich microalgae can be applied to food products as vitamin supplements, food colorant, nutraceuticals, and functional foods to promote overall health; and as feed additives for poultry, livestock, fish, and crustaceans to enhance coloration and survival [16,21]. Monoraphidium sp. GK12, a similar strain of M. convolutum GW5, has been proposed as a potential astaxanthin producer. In addition, it has been successfully cultivated in large-scale outdoor cultures and trialed in prawn farming for improving prawn pigmentation and survival $[57,89]$. In summary, $M$. convolutum GW5 is an attractive strain for carotenoid applications based on its high content of carotenoids $\left(8 \mathrm{mg} \mathrm{g}^{-1} \mathrm{DW}\right.$; Figure 6) and the ability to achieve high productivity. Furthermore, it has great potential to be cultivated at a large scale for astaxanthin production as demonstrated by the promising performance of Monoraphidium sp. GK12. Further research on M. convolutum GW5 as a source of valuable carotenoid production will rest on detailed individual carotenoid profiling, quantity and quality optimization of desired pigments through the carotenogenesis process. Recent reports on Chlorella spp. demonstrate that further increases in carotenoid biosynthesis and profile variations can be achieved by mutagenesis and induction by high light irradiation, glucose, $\mathrm{NaCl}$, and nitrogen deficiency $[99,100]$.

\section{Conclusions}

Using streamlined protocols, this study isolated and identified novel microalgal strains, and assessed their growth, biomass productivity, fatty acid content and composition, protein content, and carotenoid content. The results clearly demonstrate the naturally high growth rates and productivities of multiple promising strains under standardized 
conditions. In addition, the essential PUFA ALA, together with the very low n- $6 / \mathrm{n}-3$ ratio, and the high FA productivity suggested the suitability of Scenedesmus sp. GW63 for the production of high-quality FA oils. The high protein content and productivity, and its unique physiological response to grazers suggest that Desmodesmus sp. UQL1_26 is likely to be a reliable competitive alga when cultivated in mass outdoor open systems for protein-rich foods and feeds. Exceptionally high carotenoid content and productivity of M. convolutum GW5 were identified and highlighted as desirable traits, suggesting that this alga is an ideal candidate for high-value carotenoid production. All these characteristics confirmed great potential of Scenedesmus sp. GW63, Desmodesmus sp. UQL1_26, and M. convolutum GW5 to be exploited commercially for the production of nutraceuticals, functional foods and animal feeds. Furthermore, the combination of these three microalgae in one multi-nutrient supplement would provide add-on health and nutritional advantages, including high levels of quality FA, protein and carotenoids, respectively. Further investigations should be carried out under large-scale outdoor cultivation. Subsequently, future improvements and optimizations of desired biocompounds through manipulation of cultivation conditions, and necessary toxicity tests for these algae to be consumed by humans and animals are required. This study laid the fundamental framework for targeting high-value natural compounds from promising local microalgae for food and feed applications, through careful collection, isolation, and identification of suitable microalgae, and comparisons of biochemical contents under a standard cultivation assay. The streamlined methods are applicable to most other locations to identify high-performing local microalgal strains.

Author Contributions: Conceptualization, S.R.T.-H. and P.M.S.; methodology, B.B.; data analysis, B.B. and S.R.T.-H.; writing—original draft preparation, B.B.; writing—review and editing, S.R.T.-H. and P.M.S.; supervision, S.R.T.-H. and P.M.S.; project administration, P.M.S.; funding acquisition, P.M.S. All authors have read and agreed to the published version of the manuscript.

Funding: This work was funded by Meat \& Livestock Australia [B.NBP.0695] and a Moggill Markets Prize.

Institutional Review Board Statement: Not applicable.

Informed Consent Statement: Not applicable.

Data Availability Statement: Data is contained within the article.

Acknowledgments: We would like to thank Stephen Ryan and Cécile Fabre for assistance with experiments. We are also grateful to Björn Gosch and Dorothee Hahne (Metabolomics Australia) for assistance and advice on FAME analyses, and Tom Woods from Woods Grain Pty Ltd. for samples.

Conflicts of Interest: The authors declare no conflict of interest.

\section{References}

1. Guiry, M.D. How many species of algae are there? J. Phycol. 2012, 48, 1057-1063. [CrossRef] [PubMed]

2. Lim, D.K.; Garg, S.; Timmins, M.; Zhang, E.S.; Thomas-Hall, S.R.; Schuhmann, H.; Li, Y.; Schenk, P.M. Isolation and evaluation of oil-producing microalgae from subtropical coastal and brackish waters. PLoS ONE 2012, 7, e40751. [CrossRef] [PubMed]

3. Rodolfi, L.; Chini Zittelli, G.; Bassi, N.; Padovani, G.; Biondi, N.; Bonini, G.; Tredici, M.R. Microalgae for oil: Strain selection, induction of lipid synthesis and outdoor mass cultivation in a low-cost photobioreactor. Biotechnol. Bioeng. 2009, 102, 100-112. [CrossRef] [PubMed]

4. Borowitzka, M.; Moheimani, N. Sustainable biofuels from algae. Mitig. Adapt. Strateg. Glob. Change 2013, 18, 13-25. [CrossRef]

5. Schenk, P.M.; Thomas-Hall, S.R.; Stephens, E.; Marx, U.C.; Mussgnug, J.H.; Posten, C.; Kruse, O.; Hankamer, B. Second generation biofuels: High-efficiency microalgae for biodiesel production. BioEnergy Res. 2008, 1, 20-43. [CrossRef]

6. Khan, S.A.; Rashmi Hussain, M.Z.; Prasad, S.; Banerjee, U.C. Prospects of biodiesel production from microalgae in India. Renew. Sustain. Energy Rev. 2009, 13, 2361-2372. [CrossRef]

7. Wang, B.; Li, Y.; Wu, N.; Lan, C.Q. $\mathrm{CO}_{2}$ bio-mitigation using microalgae. Appl. Microbiol. Biotechnol. 2008, 79, 707-718. [CrossRef]

8. Chisti, Y. Biodiesel from microalgae. Biotechnol. Adv. 2007, 25, 294-306. [CrossRef]

9. Vardon, D.R.; Sharma, B.K.; Scott, J.; Yu, G.; Wang, Z.; Schideman, L.; Zhang, Y.; Strathmann, T.J. Chemical properties of biocrude oil from the hydrothermal liquefaction of Spirulina algae, swine manure, and digested anaerobic sludge. Bioresour. Technol. 2011, 102, 8295-8303. [CrossRef] [PubMed]

10. Mallick, N. Biotechnological potential of immobilized algae for wastewater N, P and metal removal: A review. BioMetals 2002, 15, 377-390. [CrossRef] 
11. Borowitzka, M.A. Commercial production of microalgae: Ponds, tanks, tubes and fermenters. J. Biotechnol. 1999, 70, 313-321. [CrossRef]

12. Stolz, P.; Obermayer, B. Manufacturing microalgae for skincare. Cosmet. Toilet. 2005, 120, 99-106.

13. Borowitzka, M. High-value products from microalgae-their development and commercialisation. J. Appl. Phycol. 2013, 25, 743-756. [CrossRef]

14. Mata, T.M.; Martins, A.A.; Caetano, N.S. Microalgae for biodiesel production and other applications: A review. Ren. Sustain. Energy Rev. 2010, 14, 217-232. [CrossRef]

15. Becker, E.W. Micro-algae as a source of protein. Biotechnol. Adv. 2007, 25, 207-210. [CrossRef] [PubMed]

16. Spolaore, P.; Joannis-Cassan, C.; Duran, E.; Isambert, A. Commercial applications of microalgae. J. Biosci. Bioeng. 2006, 101, 87-96. [CrossRef]

17. Milledge, J. Commercial application of microalgae other than as biofuels: A brief review. Rev. Environ. Sci. Bio/Technol. 2011, 10, 31-41. [CrossRef]

18. Hu, Q. Environmental effects on cell composition. In Handbook of Microalgal Culture; Richmond, A., Hu, Q., Eds.; John Wiley \& Sons Ltd.: Hoboken, NJ, USA, 2013; pp. 114-122.

19. Adarme-Vega, T.C.; Thomas-Hall, S.R.; Schenk, P.M. Towards sustainable sources for omega-3 fatty acids production. Curr. Opin. Biotechnol. 2014, 26, 14-18. [CrossRef]

20. Adarme-Vega, T.; Lim, D.K.; Timmins, M.; Vernen, F.; Li, Y.; Schenk, P.M. Microalgal biofactories: A promising approach towards sustainable omega-3 fatty acid production. Microb. Cell Factories 2012, 11, 96. [CrossRef] [PubMed]

21. Becker, E.W. Microalgae for human and animal nutrition. In Handbook of Microalgal Culture; Richmond, A., Hu, Q., Eds.; John Wiley \& Sons Ltd.: Hoboken, NJ, USA, 2013; pp. 461-503.

22. Lopez, C.V.; Garcia Mdel, C.; Fernandez, F.G.; Bustos, C.S.; Chisti, Y.; Sevilla, J.M. Protein measurements of microalgal and cyanobacterial biomass. Bioresour. Technol. 2010, 101, 7587-7591. [CrossRef]

23. Guedes, A.C.; Amaro, H.M.; Malcata, F.X. Microalgae as sources of carotenoids. Mar. Drugs 2011, 9, 625-644. [CrossRef]

24. Jin, E.; Polle, J.E.; Hong, K.L.; Sang, M.H.; Chang, M. Xanthophylls in microalgae: From biosynthesis to biotechnological mass production and application. J. Microbiol. Biotechnol. 2013, 13, 165-174.

25. Lorenz, R.T.; Cysewski, G.R. Commercial potential for Haematococcus microalgae as a natural source of astaxanthin. Trends Biotechnol. 2000, 18, 160-167. [CrossRef]

26. Renaud, S.M.; Thinh, L.-V.; Parry, D.L. The gross chemical composition and fatty acid composition of 18 species of tropical Australian microalgae for possible use in mariculture. Aquaculture 1999, 170, 147-159. [CrossRef]

27. Islam, M.; Magnusson, M.; Brown, R.; Ayoko, G.; Nabi, M.; Heimann, K. Microalgal species selection for biodiesel production based on fuel properties derived from fatty acid profiles. Energies 2013, 6, 5676-5702. [CrossRef]

28. Lang, I.; Hodac, L.; Friedl, T.; Feussner, I. Fatty acid profiles and their distribution patterns in microalgae: A comprehensive analysis of more than 2000 strains from the SAG culture collection. BMC Plant Biol. 2011, 11, 124. [CrossRef] [PubMed]

29. Batista, A.P.; Gouveia, L.; Bandarra, N.M.; Franco, J.M.; Raymundo, A. Comparison of microalgal biomass profiles as novel functional ingredient for food products. Algal Res. 2013, 2, 164-173. [CrossRef]

30. Ahmed, F.; Fanning, K.; Netzel, M.; Turner, W.; Li, Y.; Schenk, P.M. Profiling of carotenoids and antioxidant capacity of microalgae from subtropical coastal and brackish waters. Food Chem. 2014, 165, 300-306. [CrossRef] [PubMed]

31. Guillard, R.R.L.; Ryther, J.H. Studies of marine planktonic diatoms: I. Cyclotella nana Hustedt, and Dectonula confervacea (Cleve) Gran. Can. J. Microbiol. 1962, 8, 229-239. [CrossRef]

32. Duong, V.T.; Li, Y.; Nowak, E.; Schenk, P.M. Microalgae isolation and selection for prospective biodiesel production. Energies 2012, 5, 1835-1849. [CrossRef]

33. Duong, V.T.; Bao, B.; Schenk, P.M. Oleaginous microalgae isolation and screening for lipid productivity using a standard protocol. In Hydrocarbon and Lipid Microbiology Protocols; McGenity, T.J., Timmis, K.N., Nogales Fernández, B., Eds.; Springer: Berlin/Heidelberg, Germany, 2015.

34. Duong, V.T.; Ahmed, F.; Thomas-Hall, S.R.; Quigley, S.; Nowak, E.; Schenk, P.M. High protein- and high lipid-producing microalgae from northern australia as potential feedstock for animal feed and biodiesel. Front. Bioeng. Biotechnol. $2015,3,53$. [CrossRef] [PubMed]

35. Griffiths, M.; Harrison, S.L. Lipid productivity as a key characteristic for choosing algal species for biodiesel production. J. Appl. Phycol. 2009, 21, 93-507. [CrossRef]

36. Wood, A.M.; Everroad, R.C.; Wingard, L.M. Measuring growth rates in microalgal cultures. In Algal Culturing Techniques; Andersen, R.A., Ed.; Elsevier Academic Press: Burlington, MA, USA, 2005; pp. 269-285.

37. Nei, M.; Kumar, S. Molecular Evolution and Phylogenetics; Oxford University Press: New York, NY, USA, 2000.

38. Tamura, K.; Peterson, D.; Peterson, N.; Stecher, G.; Nei, M.; Kumar, S. MEGA5: Molecular evolutionary genetics analysis using maximum likelihood, evolutionary distance, and maximum parsimony methods. Mol. Biol. Evol. 2011, 28, 2731-2739. [CrossRef]

39. Hall, B.G. Building phylogenetic trees from molecular data with MEGA. Mol. Biol. Evol. 2013, 30, 1229-1235. [CrossRef]

40. Lowry, O.H.; Rosebrough, N.J.; Farr, A.L.; Randall, R.J. Protein measurement with the Folin phenol reagent. J. Biol. Chem. 1951, 193, 265-275. [CrossRef] 
41. Huang, J.J.; Cheung, P.C. +UVA treatment increases the degree of unsaturation in microalgal fatty acids and total carotenoid content in Nitzschia closterium (Bacillariophyceae) and Isochrysis zhangjiangensis (Chrysophyceae). Food Chem. 2011, 129, 783-791. [CrossRef]

42. Porra, R.; Thompson, W.; Kriedemann, P. Determination of accurate extinction coefficients and simultaneous equations for assaying chlorophylls a and b extracted with four different solvents: Verification of the concentration of chlorophyll standards by atomic absorption spectroscopy. Biochim. Biophys. Acta 1989, 975, 384-394. [CrossRef]

43. An, S.S.; Friedl, T.; Hegewald, E. Phylogenetic relationships of Scenedesmus and Scenedesmus-like coccoid green algae as Inferred from ITS-2 rDNA sequence comparisons. Plant Biol. 1999, 1, 418-428. [CrossRef]

44. Borowitzka, M. Species and strain selection. In Developments in Applied Phycology; Borowitzka, M.A., Moheimani, N.R., Eds.; Springer: Dordrecht, The Netherlands, 2013; Volume 5, pp. 77-89.

45. Barclay, W.; Apt, K. Strategies for bioprospecting microalgae for potential commercial applications. In Handbook of Microalgal Culture; Richmond, A., Hu, Q., Eds.; John Wiley \& Sons Ltd.: Hoboken, NJ, USA, 2013; pp. 69-79.

46. Friedl, T.; O'Kelly, C.J. Phylogenetic relationships of green algae assigned to the genus Planophila (Chlorophyta): Evidence from $18 \mathrm{~S}$ rDNA sequence data and ultrastructure. Eur. J. Phycol. 2002, 37, 373-384. [CrossRef]

47. Krienitz, L.; Bock, C.; Nozaki, H.; Wolf, M. SSU rRNA gene phylogeny of morphospecies affiliated to the bioassay alga "Selenastrum capricornutum" recovered the polyphyletic origin of crescent-shaped Chlorophyta. J. Phycol. 2011, 47, 880-893. [CrossRef]

48. Leliaert, F.; Verbruggen, H.; Vanormelingen, P.; Steen, F.; López-Bautista, J.M.; Zuccarello, G.C.; De Clerck, O. DNA-based species delimitation in algae. Eur. J. Phycol. 2014, 49, 179-196. [CrossRef]

49. Moon-van der Staay, S.Y.; De Wachter, R.; Vaulot, D. Oceanic $18 \mathrm{~S}$ rDNA sequences from picoplankton reveal unsuspected eukaryotic diversity. Nature 2001, 409, 607-610. [CrossRef]

50. Piganeau, G.; Eyre-Walker, A.; Grimsley, N.; Moreau, H. How and why DNA barcodes underestimate the diversity of microbial eukaryotes. PLoS ONE 2011, 6, e16342. [CrossRef] [PubMed]

51. Andersen, R.A. The microalgal cell. In Handbook of Microalgal Culture; Richmond, A., Hu, Q., Eds.; John Wiley \& Sons Ltd.: Hoboken, NJ, USA, 2013; pp. 1-20.

52. Lürling, M. Phenotypic plasticity in the green algae Desmodesmus and Scenedesmus with special reference to the induction of defensive morphology. Ann. Limnol. Int. J. Limnol. 2009, 39, 85-101. [CrossRef]

53. Alpermann, T.J.; Tillmann, U.; Beszteri, B.; Cembella, A.D.; John, U. Phenotypic variation and genotypic diversity in a planktonic population of the toxigenic marine dinoflagellate Alexandrium tamarense (Dinophyceae). J. Phycol. 2010, 46, 18-32. [CrossRef]

54. Luo, W.; Pflugmacher, S.; Proschold, T.; Walz, N.; Krienitz, L. Genotype versus phenotype variability in Chlorella and Micractinium (Chlorophyta, Trebouxiophyceae). Protist 2006, 157, 315-333. [CrossRef]

55. Fawley, M.W.; Dean, M.L.; Dimmer, S.K.; Fawley, K.P. Evaluating the Morphospecies Concept in the Selenastraceae (Chlorophyceae, Chlorophyta)1. J. Phycol. 2005, 42, 142-154. [CrossRef]

56. Krienitz, L.; Ustinova, I.; Friedl, T.; Huss, V.A.R. Traditional generic concepts versus $18 \mathrm{~S}$ rRNA gene phylogeny in the green algal family selenastraceae (chlorophyceae, chlorophyta). J. Phycol. 2001, 37, 852-865. [CrossRef]

57. Fujii, K.; Nakajima, H.; Anno, Y. Potential of Monoraphidium sp. GK12 for energy-saving astaxanthin production. J. Chem. Technol. Biotechnol. 2008, 83, 1578-1584. [CrossRef]

58. Ruangsomboon, S.; Ganmanee, M.; Choochote, S. Effects of different nitrogen, phosphorus, and iron concentrations and salinity on lipid production in newly isolated strain of the tropical green microalga, Scenedesmus dimorphus KMITL. J. Appl. Phycol. 2012, 25, 867-874. [CrossRef]

59. Vidyashankar, S.; Deviprasad, K.; Chauhan, V.S.; Ravishankar, G.A.; Sarada, R. Selection and evaluation of $\mathrm{CO}_{2}$ tolerant indigenous microalga Scenedesmus dimorphus for unsaturated fatty acid rich lipid production under different culture conditions. Bioresour. Technol. 2013, 144, 28-37. [CrossRef]

60. Yu, X.; Zhao, P.; He, C.; Li, J.; Tang, X.; Zhou, J.; Huang, Z. Isolation of a novel strain of Monoraphidium sp. and characterization of its potential application as biodiesel feedstock. Bioresour. Technol. 2012, 121, 256-262. [CrossRef]

61. Radzun, K.A.; Wolf, J.; Jakob, G.; Zhang, E.; Stephens, E.; Ross, I.; Hankamer, B. Automated nutrient screening system enables high-throughput optimisation of microalgae production conditions. Biotechnol. Biofuels 2015, 8, 65. [CrossRef] [PubMed]

62. Huerlimann, R.; de Nys, R.; Heimann, K. Growth, lipid content, productivity, and fatty acid composition of tropical microalgae for scale-up production. Biotechnol. Bioeng. 2010, 107, 245-257. [CrossRef] [PubMed]

63. Lawton, R.J.; de Nys, R.; Paul, N.A. Selecting reliable and robust freshwater macroalgae for biomass applications. PLoS ONE 2013, 8, e64168. [CrossRef] [PubMed]

64. Nascimento, I.A.; Marques, S.S.I.; Cabanelas, I.T.D.; Pereira, S.A.; Druzian, J.I.; de Souza, C.O.; Vich, D.V.; de Carvalho, G.C.; Nascimento, M.A. Screening microalgae strains for biodiesel production: Lipid productivity and estimation of fuel quality aased on fatty acids profiles as selective criteria. BioEnergy Res. 2012, 6, 1-13. [CrossRef]

65. Voltolina, D.; Cordero, B.; Nieves, M.; Soto, L.P. Growth of Scenedesmus sp. in artificial wastewater. Bioresour. Technol. 1999, 68, 265-268. [CrossRef]

66. Gouveia, L.; Oliveira, A.C. Microalgae as a raw material for biofuels production. J. Ind. Microbiol. Biotechnol. 2009, 36, 269-274. [CrossRef]

67. Via, S.; Lande, R. Genotype-environment interaction and the evolution of phenotypic plasticity. Evolution 1985, 39, 505-522. [CrossRef] 
68. Chen, C.Y.; Yeh, K.L.; Aisyah, R.; Lee, D.J.; Chang, J.S. Cultivation, photobioreactor design and harvesting of microalgae for biodiesel production: A critical review. Bioresour. Technol. 2011, 102, 71-81. [CrossRef]

69. Hu, Q.; Sommerfeld, M.; Jarvis, E.; Ghirardi, M.; Posewitz, M.; Seibert, M.; Darzins, A. Microalgal triacylglycerols as feedstocks for biofuel production: Perspectives and advances. Plant J. 2008, 54, 621-639. [CrossRef]

70. Bischoff, H.W.; Bold, H.C. Some Soil Algae from Enchanted Rock and Related Algal Species; University of Texas: Austin, TX, USA, 1963; Volume 4.

71. Allen, M.M.; Stanier, R.Y. Growth and division of some unicellular blue-green algae. J. Gen. Microbiol. 1968, 51, 199-202. [CrossRef]

72. Chen, M.; Tang, H.; Ma, H.; Holland, T.C.; Ng, K.Y.; Salley, S.O. Effect of nutrients on growth and lipid accumulation in the green algae Dunaliella tertiolecta. Bioresour. Technol. 2011, 102, 1649-1655. [CrossRef]

73. Samori, G.; Samori, C.; Guerrini, F.; Pistocchi, R. Growth and nitrogen removal capacity of Desmodesmus communis and of a natural microalgae consortium in a batch culture system in view of urban wastewater treatment: Part I. Water Res. 2013, 47, 791-801. [CrossRef]

74. Richmond, A. Biological Principles of Mass Cultivation of Photoautotrophic Microalgae. In Handbook of Microalgal Culture; Richmond, A., Ed.; John Wiley \& Sons Ltd.: Hoboken, NJ, USA, 2013; pp. 169-204.

75. Gosch, B.J.; Magnusson, M.; Paul, N.A.; de Nys, R. Total lipid and fatty acid composition of seaweeds for the selection of species for oil-based biofuel and bioproducts. GCB Bioenergy 2012, 4, 919-930. [CrossRef]

76. Kent, M.; Welladsen, H.M.; Mangott, A.; Li, Y. Nutritional evaluation of Australian microalgae as potential human health supplements. PLoS ONE 2015, 10, e0118985. [CrossRef]

77. Martínez-Fernández, E.; Acosta-Salmón, H.; Southgate, P.C. The nutritional value of seven species of tropical microalgae for black-lip pearl oyster (Pinctada margaritifera, L.) larvae. Aquaculture 2006, 257, 491-503. [CrossRef]

78. Patil, V.; Källqvist, T.; Olsen, E.; Vogt, G.; Gislerød, H.R. Fatty acid composition of 12 microalgae for possible use in aquaculture feed. Aquacult. Int. 2006, 15, 1-9. [CrossRef]

79. Poudyal, H.; Panchal, S.K.; Waanders, J.; Ward, L.; Brown, L. Lipid redistribution by alpha-linolenic acid-rich chia seed inhibits stearoyl-CoA desaturase-1 and induces cardiac and hepatic protection in diet-induced obese rats. J. Nutr. Biochem. 2012, 23, 153-162. [CrossRef] [PubMed]

80. Dubois, V.; Breton, S.; Linder, M.; Fanni, J.; Parmentier, M. Fatty acid profiles of 80 vegetable oils with regard to their nutritional potential. Eur. J. Lipid Sci. Technol. 2007, 109, 710-732. [CrossRef]

81. Martins, D.A.; Custodio, L.; Barreira, L.; Pereira, H.; Ben-Hamadou, R.; Varela, J.; Abu-Salah, K.M. Alternative sources of n-3 long-chain polyunsaturated fatty acids in marine microalgae. Mar. Drugs 2013, 11, 2259-2281. [CrossRef] [PubMed]

82. Simopoulos, A.P. The importance of the omega-6/omega-3 fatty acid ratio in cardiovascular disease and other chronic diseases. Exp. Biol. Med. 2008, 233, 674-688. [CrossRef]

83. Bell, M.; Tocher, D. Biosynthesis of polyunsaturated fatty acids in aquatic ecosystems: General pathways and new direction. In Lipids in Aquatic Ecosystems; Kainz, M., Brett, M.T., Arts, M.T., Eds.; Springer: New York, NY, USA, 2009; pp. $211-236$.

84. Hempel, N.; Petrick, I.; Behrendt, F. Biomass productivity and productivity of fatty acids and amino acids of microalgae strains as key characteristics of suitability for biodiesel production. J. Appl. Phycol. 2012, 24, 1407-1418. [CrossRef]

85. Sharma, K.K.; Schuhmann, H.; Schenk, P.M. High lipid induction in microalgae for biodiesel production. Energies 2012, 5, 1532-1553. [CrossRef]

86. Herrero, M.; Mendiola, J.; Plaza, M.; Ibañez, E. Screening for bioactive compounds from algae. In Advanced Biofuels and Bioproducts; Lee, J.W., Ed.; Springer: New York, NY, USA, 2013; pp. 833-872.

87. Wright, T.; Lackey, R. Definitions of Feed Manufacturing and Livestock Nutrition Terms, Ontario Ministry of Agriculture, Food, and Rural Affairs. 2008. Available online: http:/ / www.omafra.gov.on.ca/english/livestock/dairy/facts/08-039.pdf (accessed on 18 October 2015).

88. Fujii, K.; Nakashima, H.; Hashidzume, Y.; Uchiyama, T.; Mishiro, K.; Kadota, Y. Potential use of the astaxanthin-producing microalga, Monoraphidium sp. GK12, as a functional aquafeed for prawns. J. Appl. Phycol. 2009, 22, 363-369. [CrossRef]

89. Seyfabadi, J.; Ramezanpour, Z.; Amini Khoeyi, Z. Protein, fatty acid, and pigment content of Chlorella vulgaris under different light regimes. J. Appl. Phycol. 2011, 23, 721-726. [CrossRef]

90. Lee, Y.-K.; Chen, W.; Shen, H.; Han, D.; Li, Y.; Jones, H.D.T.; Timlin, J.A.; Hu, Q. Basic culturing and analytical measurement techniques. In Handbook of Microalgal Culture; Richmond, A., Ed.; John Wiley \& Sons Ltd.: Hoboken, NJ, USA, 2013 ; pp. 37-68.

91. Pignolet, O.; Jubeau, S.; Vaca-Garcia, C.; Michaud, P. Highly valuable microalgae: Biochemical and topological aspects. J. Ind. Microbiol. Biotechnol. 2013, 40, 781-796. [CrossRef]

92. Chan, M.-C.; Ho, S.-H.; Lee, D.-J.; Chen, C.-Y.; Huang, C.-C.; Chang, J.-S. Characterization, extraction and purification of lutein produced by an indigenous microalga Scenedesmus obliquus CNW-N. Biochem. Eng. J. 2013, 78, 24-31. [CrossRef]

93. Schüler, L.; Greque de Morais, E.; Trovão, M.; Machado, A.; Carvalho, B.; Carneiro, M.; Maia, I.; Soares, M.; Duarte, P.; Barros, A.; et al . Isolation and characterization of novel Chlorella vulgaris mutants with low chlorophyll and improved protein contents for food applications. Front. Bioeng. Biotechnol. 2020, 8, 469. [CrossRef]

94. Mendes-Pinto, M.M.; Raposo, M.F.J.; Bowen, J.; Young, A.J.; Morais, R. Evaluation of different cell disruption processes on encysted cells of Haematococcus pluvialis: Effects on astaxanthin recovery and implications for bio-availability. J. Appl. Phycol. 2001, 13, 19-24. [CrossRef] 
95. Boussiba, S. Carotenogenesis in the green alga Haematococcus pluvialis: Cellular physiology and stress response. Physiol. Plant. 2000, 108, 111-117. [CrossRef]

96. Borowitzka, M.A. Dunaliella: Biology, production, and markets. In Handbook of Microalgal Culture; Richmond, A., Hu, Q., Eds.; John Wiley \& Sons Ltd.: Hoboken, NJ, USA, 2013; pp. 359-368.

97. Han, D.; Li, Y.; Hu, Q. Biology and commercial aspects of Haematococcus pluvialis. In Handbook of Microalgal Culture; Richmond, A., Hu, Q., Eds.; John Wiley \& Sons Ltd.: Hoboken, NJ, USA, 2013; pp. 388-405.

98. Latasa, M.; Van Lenning, K.; Garrido, J.; Scharek, R.; Estrada, M.; Rodríguez, F.; Zapata, M. Losses of chlorophylls and carotenoids in aqueous acetone and methanol extracts prepared for RPHPLC analysis of pigments. Chromatographia 2001, 53, 385-391. [CrossRef]

99. Kim, J.; Kim, M.; Lee, S.; Jin, E. Development of a Chlorella vulgaris mutant by chemical mutagenesis as a producer for natural violaxanthin. Algal Res. 2020, 46, 101790. [CrossRef]

100. Huang, W.; Lin, Y.; He, M.; Gong, Y.; Huang, J. Induced high-yield production of zeaxanthin, lutein, and $\beta$-carotene by a mutant of Chlorella zofingiensis. J. Agricult. Food Chem. 2018, 66, 891-897. [CrossRef] [PubMed] 